\title{
Sphingomonas pituitosa sp. nov., an exopolysaccharide-producing bacterium that secretes an unusual type of sphingan
}

\footnotetext{
1 Institut für Mikrobiologie und Genetik, Universität Wien, A-1030 Wien, Austria

2 Institut für Angewandte Mikrobiologie, JustusLiebig-Universität Giessen, D-35390 Giessen, Germany

3 Bereich Mikrobiologie, Gesellschaft für Biotechnologische Forschung, D-38124 Braunschweig, Germany

4 Institut für Bakteriologie, Mykologie und Hygiene, Veterinärmedizinische Universität, A-1210 Wien, Austria

5 Botanisches Institut der Universität München, D-80683 München, Germany
}

\author{
Ewald B. M. Denner, ${ }^{1}$ Susanne Paukner, ${ }^{1}$ Peter Kämpfer, ${ }^{2}$ \\ Edward R. B. Moore, ${ }^{3}$ Wolf-Rainer Abraham, ${ }^{3}$ Hans-Jürgen Busse, ${ }^{1,4}$ \\ Gerhard Wanner ${ }^{5}$ and Werner Lubitz ${ }^{1}$
}

Author for correspondence: Ewald B. M. Denner. Tel: +43 14277 54632. Fax: +43 142779546. e-mail:denner@gem.univie.ac.at

\begin{abstract}
Strain EDIV', an exopolysaccharide-producing bacterium, was subjected to polyphasic characterization. The bacterium produced copious amounts of an extracellular polysaccharide, forming slimy, viscous, intensely yellowpigmented colonies on Czapek-Dox (CZD) agar. The culture fluids of the liquid version of CZD medium were highly viscous after cultivation for $5 \mathrm{~d}$. Cells of strain EDIV were Gram-negative, catalase-positive, oxidase-negative, nonspore-forming, rod-shaped and motile. Comparisons of 16S rDNA gene sequences demonstrated that EDIV ${ }^{\top}$ clusters phylogenetically with the species of the genus Sphingomonas sensu stricto. The G+C content of the DNA (64.5 $\mathrm{mol} \%$ ), the presence of ubiquinone Q-10, the presence of 2hydroxymyristic acid (14:0 2-OH) as the major hydroxylated fatty acid, the absence of 3-hydroxy fatty acids and the detection of sym-homospermidine as the major component in the polyamine pattern, together with the presence of sphingoglycolipid, supported this delineation. 16S rDNA sequence analysis indicated that strain EDIV is most closely related ( $99 \cdot 4 \%$ similarity) to Sphingomonas trueperi LMG $2142{ }^{\top}$. DNA-DNA hybridization showed that the

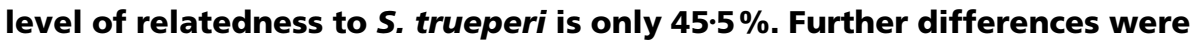
apparent in the cellular fatty acid profile, the polar lipid pattern, the Fouriertransform infrared spectrum and whole-cell proteins and in a number of biochemical characteristics. On the basis of the estimated phylogenetic position derived from 16S rDNA sequence data, DNA-DNA reassociation and phenotypic differences, strain EDIV ${ }^{\top}\left(=\right.$ CIP $^{106154}{ }^{\top}=$ DSM 13101') was $^{\top}$ recognized as a new species of Sphingomonas, for which the name Sphingomonas pituitosa sp. nov. is proposed. A component analysis of the exopolysaccharide (named PS-EDIV) suggested that it represents a novel type of sphingan composed of glucose, rhamnose and an unidentified sugar. Glucuronic acid, which is commonly found in sphingans, was absent. The mean molecular mass of PS-EDIV was approximately $3 \times 10^{6} \mathrm{Da}$.
\end{abstract}

Keywords: Sphingomonas pituitosa sp. nov., polyphasic characterization, exopolysaccharide, sphingan

\section{INTRODUCTION}

Interest in the genus Sphingomonas is becoming

Abbreviations: FT-IR, Fourier-transform infrared; PHB, poly- $\beta$-hydroxybutyrate.

The EMBL accession number for the $16 \mathrm{~S}$ rDNA sequence of Sphingomonas pituitosa strain EDIV' is AJ243751. increasingly intense, as there have been several recent reports on the broad catabolic capabilities of strains of Sphingomonas species. These organisms have great potential for biotechnological applications in the degradation, bioremediation and wastewater treatment of xenobiotic pollutants (e.g. Fredrickson et al., 1991, 1995; Harms et al., 1995; Karlson et al., 1995; Mueller et al., 1990; Nohynek et al., 1996a, b; Wittich 
et al., 1992; Zipper et al., 1996), as bacterial antagonists of phytopathogenic fungi (Berg \& Balin, 1994) and for the production of industrially useful exopolysaccharides (Moorehouse, 1987; Chandrasekaran \& Radha, 1995). Certain structurally related exopolysaccharides referred to as 'sphingans' (Pollock, 1993) are synthesized by several Sphingomonas strains, and include the following: heteropolysaccharide S-7 (Kang \& McNeely, 1976), gellan (S-60), S-88, welan (S-130) (Kang \& Veeder, 1982a, b, 1985; Kang et al., 1982; O'Neill et al., 1983), rhamsan (S194) (Peik et al., 1983), S-198 (Peik et al., 1985), S-657 (Chowdhury et al., 1987b), NW11 (Robison \& Stipanovic, 1989), PS-P4 (Lobas et al., 1994), GS-1 (Ashtaputre \& Shah, 1995), I-886 (Falk et al., 1996) and HWR1 (Hashimoto \& Murato, 1998). Sphingans share the same carbohydrate-backbone structure (-X-glucose-glucuronic acid-glucose- $\mathrm{X}-$, where $\mathrm{X}$ is either L-rhamnose or L-mannose), to which distinct side-groups are attached, influencing their rheological properties. Sphingan-producing bacteria were classified originally into diverse genera such as Alcaligenes, Azotobacter, Pseudomonas, Xanthobacter and Xanthomonas, although a re-examination of their phenotypic characteristics indicated that they are all closely related to each other and to Sphingomonas species (Pollock, 1993).

A series of polyphasic taxonomic studies has demonstrated that sphingomonads can be recognized at the genus and species level by the employment of chemotaxonomic methods (Yabuuchi et al., 1990; Takeuchi et al., 1993, 1995; Nohynek et al., 1996a, b; Balkwill et al., 1997; Kämpfer et al., 1997; Denner et al., 1999, Busse et al., 1999; Stolz et al., 2000; Yun et al., 2000). The sphingomonads that have been analysed so far are characterized by the presence of ubiquinone Q-10 as the major respiratory lipoquinone and sym-homospermidine or spermidine as the characteristic compound in the polyamine pattern. The $\mathrm{G}+\mathrm{C}$ contents of genomic DNAs range from 61.6 to $67 \cdot 8 \mathrm{~mol} \%$. Furthermore, sphingomonads contain 2-hydroxymyristic acid $(14: 02-\mathrm{OH})$ as the major hydroxylated fatty acid, do not contain 3-hydroxy fatty acids and do not contain the lipopolysaccharide characteristic of Gramnegative bacteria. In contrast, they have sphingoglycolipids as major components in their cellular lipids and most species contain the carotenoid pigment nostoxanthin. A high degree of qualitative and quantitative variety in the polar lipid composition of sphingomonads, which is useful for their characterization and preliminary identification, was also observed. However, the presence of the unique sphingoglycolipids is a characteristic marker for the genus Sphingomonas and closely related genera. Combined analyses of these chemotaxonomic features appear to provide useful chemosystematic signatures for their identification at the family level and to the species level when these approaches are applied in combination (Kämpfer et al., 1997; Denner et al., 1999; Busse et al., 1999).
In the study presented here, we report the polyphasic taxonomic characterization of a novel exopolysaccharide-producing Sphingomonas isolate, strain EDIV $^{\mathrm{T}}$. The phenotypic properties, chemotaxonomic characteristics and 16S rRNA gene sequence of this organism are described and its phylogenetic position among the sphingomonads is discussed. In addition, a first component analysis of the exopolysaccharide secreted by the bacterium was also performed.

\section{METHODS}

Source of strains, cultivation and maintenance. The bacterium (designated EDIV $^{\mathrm{T}}$ ) investigated in this study was isolated originally from a water sample taken from a eutrophic fountain in Vienna (Austria) in which an algal bloom was observed; isolation was by plating onto CzapekDox agar (CZD; Oxoid). Reference type strains Sphingomonas echinoides DSM 1805 ${ }^{\mathrm{T}}$, Sphingomonas parapaucimobilis DSM 7463 ${ }^{\mathrm{T}}$ and Sphingomonas paucimobilis DSM $1098^{\mathrm{T}}$ were obtained from the DSMZ, Braunschweig, Germany. Sphingomonas adhaesiva IFO 15099 ${ }^{\mathrm{T}}$, Sphingomonas mali IFO $15500^{\mathrm{T}}$, Sphingomonas pruni IFO $15498^{\mathrm{T}}$ and Sphingomonas sanguinis IFO $13937^{\mathrm{T}}$ were obtained from M. Salkinoja-Salonen (Department of Applied Microbiology and Biochemistry, University of Helsinki, Helsinki, Finland). Sphingomonas trueperi ATCC $12417^{\mathrm{T}}$ was obtained from G. Auling (Institute of Microbiology, University of Hannover, Hannover, Germany). All bacterial strains were stored at $-70^{\circ} \mathrm{C}$ in tryptone soy broth (TSB; Oxoid) containing $20 \%$ glycerol. Bacterial inocula for all experiments were taken from these glycerol stocks, streaked onto tryptone soy agar (TSA; Oxoid) and incubated aerobically at $28-30^{\circ} \mathrm{C}$ for $48 \mathrm{~h}$; all experiments were performed twice.

Microscopy. Cell morphology and motility were examined by phase-contrast microscopy (Leitz, Diaplan) from overnight cultures grown in TSB at $28-30{ }^{\circ} \mathrm{C}$ on a rotary shaker (150 r.p.m.). Cell size was estimated by DAPI $\left(4^{\prime}, 6-\right.$ diamidino-2-phenylindole) staining according to Porter \& Feig (1990), as modified by Sherr et al. (1992). Flagellar arrangement was examined by using the procedure of Kodaka et al. (1982). The Gram reaction was determined by staining and was confirmed by the $\mathrm{KOH}$ test as described by Smibert \& Krieg (1994). For electron microscopy, cells were washed three times with a buffer ( $\mathrm{pH} 7 \cdot 2$ ) containing $2 \mathrm{mM}$ $\mathrm{MgSO}_{4}$ and $75 \mathrm{mM}$ sodium cacodylate and then fixed with $2 \%$ glutaraldehyde, in the same buffer, at room temperature for $1 \mathrm{~h}$ and washed again. The cells were prepared for transmission electron microscopy as described by Witte et al. (1990). Transmission electron microscopy was performed using a ZEO 912 Omega 101 transmission electron microscope operated at $80 \mathrm{kV}$ in the zero-loss mode.

Cultural and biochemical characterization. Colony morphology was described from cultures grown aerobically on complex peptone-containing standard media including TSA, Luria-Bertani agar (Atlas, 1995) and nutrient agar (Merck), as well as on low-nutrient medium R2A agar (Oxoid); the individual media were incubated at $28-30^{\circ} \mathrm{C}$ for $24-72 \mathrm{~h}$. Growth at 4, 37 and $45^{\circ} \mathrm{C}$ was tested for as long as 2 weeks. Susceptibility to eight antimicrobial agents of strain EDIV ${ }^{\mathrm{T}}$, S. paucimobilis DSM $1098^{\mathrm{T}}$ and S. trueperi ATCC $12417^{\mathrm{T}}$ was tested by the disc diffusion method, as described by Jorgensen et al. (1999), using antibiotic-impregnated discs 
(Oxoid). Briefly, $100 \mu$ of a bacterial suspension, with an optical density equivalent to that of a $0.5 \mathrm{McF}$ arland standard, was plated onto Iso-Sensitest agar (Oxoid). The following antibiotics were tested ( $\mu \mathrm{g}$ antibiotic per disk in parentheses): ampicillin (10), chloramphenicol (30), gentamicin (10), kanamycin (30), streptomycin (10), penicillin G (10 IU), polymyxin B (300 IU) and tetracycline (30). Any sign of growth inhibition after $48 \mathrm{~h}$ incubation at $28-30{ }^{\circ} \mathrm{C}$ was scored as sensitivity to that antibiotic. Resistance to an antimicrobial drug was indicated if no inhibition zone was observed.

Oxidase activity was tested for by using Bactident-Oxidase test strips (Merck) according to the manufacturer's instructions and by using the Kovac test (Smibert \& Krieg, 1994). Initial identification was performed using API $20 \mathrm{NE}$ galleries (bioMérieux). Detailed biochemical characterization was performed by using the miniaturized assay method, as described previously (Kämpfer et al., 1991; Kämpfer \& Altwegg, 1992), and by conventional testing, as described by Smibert \& Krieg (1994), which included the test for catalase activity, the Hugh-Leifson oxidativefermentative test and tests for nitrate reduction, $\mathrm{H}_{2} \mathrm{~S}$ production, citrate utilization (Simmons), indole production and hydrolysis of Tween 80, starch and casein. DNase production was examined in cultures grown for $48 \mathrm{~h}$ on DNase test agar (Oxoid) at $28-30{ }^{\circ} \mathrm{C}$. The accumulation of poly- $\beta$-hydroxybutyrate (PHB) was evaluated by GC from freeze-dried cell material, as described previously (Schroll et al., 1996).

Chemotaxonomic investigations. Respiratory lipoquinones were extracted from $100 \mathrm{mg}$ lyophilized cell material with methanol/hexane $(2: 1, \mathrm{v} / \mathrm{v})$ as described by Tindall (1990). The hexane phase, containing the respiratory lipoquinones, was separated by TLC on silica-gel $\mathrm{F}_{254}$ plates (Merck) with hexane/tetra-butyl methyl ether $(9: 1, \mathrm{v} / \mathrm{v})$ as the solvent system and compared with commercially available ubiquinones 9 and 10 (Sigma) on the basis of $R_{\mathrm{f}}$ values (Collins, 1994). UV-absorbing bands corresponding to ubiquinones were removed from the plate, eluted in acetone, evaporated under a stream of nitrogen and subsequently dissolved in $100 \mu \mathrm{l}$ hexane. A $10 \mu \mathrm{l}$ volume of the hexane extract was analysed by HPLC (Waters Instruments), using butylchloride/methanol (1:9, v/v) as the eluant. Respiratory lipoquinones were detected by absorbance at $269 \mathrm{~nm}$. Polyamines were extracted as described by Busse \& Auling (1988) and were analysed according to Busse et al. (1997). Fatty acid methyl esters were extracted and prepared using the standard protocol of the MIDI/Hewlett Packard Microbial Identification System. Fatty acid methyl ester extracts were analysed using a Hewlett Packard (model HP6890A) GC equipped with a flame-ionization detector, an automatic sampler, an integrator and a computer, as described previously (Kämpfer \& Kroppenstedt, 1996). Polar lipids were extracted from $100 \mathrm{mg}$ lyophilized cell material by the modified Folch procedure devised by Bligh \& Dyer (1959) and resolved in $250 \mu \mathrm{l}$ chloroform/methanol $(2: 1, \mathrm{v} / \mathrm{v})$. Extracted lipids were separated by twodimensional TLC using $10 \times 10 \mathrm{~cm}$ silica-gel $\mathrm{F}_{254}$ plates (Merck). Chloroform/methanol/water $(65: 25: 4$, by vol.) was used as the first solvent system and chloroform/ methanol/glacial acetic acid/water ( $80: 12: 15: 4$, by vol.) was used as the second solvent system. Individual lipids were detected by using the following spray reagents: ninhydrin, to detect lipids containing free amino groups (Consden \& Gordon, 1948); Zinzadze reagent, to detect lipids containing phosphate esters (Dittmer \& Lester, 1964); Dragendorff reagent, to detect lipids containing quaternary nitrogen compounds (Wagner et al., 1961; Beiss, 1964); and $\alpha$ naphthol, to visualize carbohydrate-containing lipids (glycolipids) (Jacin \& Mishkin, 1965). Molybdatophosphoric acid was used to obtain a fingerprint of the total lipid content (Gunstone \& Jacobsberg, 1972). Subsequently, lipids were identified by comparing $R_{\mathrm{f}}$ values, using commercially prepared standards (Sigma) and lipid extracts from reference type strains.

Pigment analysis. A $100 \mathrm{mg}$ quantity of cell material grown on TSA for $48 \mathrm{~h}$ at $28-30^{\circ} \mathrm{C}$ was scraped from the agar surface and placed into a small $(5 \mathrm{ml})$ Teflon-sealed glass vial. Acetone $(2 \mathrm{ml})$ was added to extract acetone-soluble pigments. After centrifugation at $10000 \mathrm{~g}$ at $4{ }^{\circ} \mathrm{C}$ for $5 \mathrm{~min}$, the supernatant was scanned for absorbance by using a Hitachi S-2000 spectrophotometer. Pure acetone was used as the blank and acetone extracts of the yellow pigments of S. paucimobilis DSM $1098^{\mathrm{T}}$ and S. trueperi ATCC $12417^{\mathrm{T}}$ grown under the same conditions were used as references.

Analysis of whole-cell protein patterns. SDS-PAGE of whole-cell proteins was performed according to Laemmli (1970). Briefly, approximately $60 \mathrm{mg}$ cells (wet weight) grown on TSA for $48 \mathrm{~h}$ at $28-30^{\circ} \mathrm{C}$ was harvested by centrifugation, resuspended in $300 \mu \mathrm{l}$ SDS sample buffer containing $150 \mu \mathrm{l}$ Laemmli buffer and $150 \mu \mathrm{l}$ phosphate buffer ( $5 \mathrm{mM}$, pH 6.8), boiled for $10 \mathrm{~min}$ and centrifuged at $10000 \mathrm{~g}$ for $15 \mathrm{~min}$ to remove any precipitate. About $4 \mu \mathrm{l}$ sample was loaded onto a $12 \%$ polyacrylamide gel. Proteins were visualized by staining with Coomassie blue R 250 . A broad-range protein marker containing proteins from $2 \cdot 3$ to $212 \mathrm{kDa}$ was used as a reference (New England BioLabs).

Fourier-transform infrared (FT-IR) spectroscopy. Bacterial films for FT-IR analysis were prepared from EDIV ${ }^{\mathrm{T}}$, as well as from reference strain $S$. trueperi ATCC $12417^{\mathrm{T}}$ grown on TSA at $28-30^{\circ} \mathrm{C}$ for $48 \mathrm{~h}$, by resuspending a loopful $(1 \mathrm{~mm}$ diameter) of cells in $80 \mu$ l deionized water and applying an aliquot of $35 \mu \mathrm{l}$ to a preformed sample area on a zinc selenite optical plate (Bruker). Following the drying of samples under reduced pressure, spectra between wave number 4000 and $500 \mathrm{~cm}^{-1}$ were recorded using an FT-IR spectrometer (type IFS 28/B; Bruker), as described by Helm et al. (1991a, b). Data analysis was carried out using opus 3.0 software (Bruker) for bacterial identification. At least six independent preparations of each strain were measured and a mean spectrum was calculated.

Determination and analysis of 16S rRNA gene sequence. Genomic DNA was prepared from individual colonies picked from agar medium, resuspended in $100 \mu \mathrm{TE}$ buffer and heated at $95{ }^{\circ} \mathrm{C}$ for $5 \mathrm{~min}$. After cooling on ice, cell debris was pelleted in a microfuge for $30 \mathrm{~s}$. Genomic DNA in the supernatant was concentrated by using Microcon-100 spin concentrators (Amicon) and was resuspended in $10 \mu \mathrm{l}$ TE buffer. The $16 \mathrm{~S}$ rRNA genes were targeted for amplification by PCR using a $1 \mu$ laliquot of the DNA suspension, a forward primer hybridizing at the complement of positions 8-27 and a reverse primer hybridizing at positions 1525-1541 (Escherichia coli numbering) and reaction conditions described in detail previously (Karlson et al., 1995). The 16S rDNA PCR products were purified by using Microcon-100 spin concentrators and were sequenced directly using a Perkin-Elmer/Applied Biosystems 373A DNA sequencer and the protocols of the manufacturer (Perkin-Elmer/ Applied Biosystems) for Taq cycle sequencing and fluorescent dye-labelled dideoxynucleotides. 
The nearly complete gene sequence of strain EDIV ${ }^{\mathrm{T}}$ was confirmed in this study by determining the sequences of PCR products produced by two separate reactions. Additionally, all sequences have been determined by overlapping sequences in both the forward and reverse directions. Sequence data were aligned with reference rRNA (and rRNA gene) sequences (Maidak et al., 1999) using evolutionarily conserved primary sequences and secondary structures as references (Gutell et al., 1985). Distance and cluster analyses were carried out using programs contained in PHYLIP version 3.5c (Felsenstein, 1993).

DNA-DNA hybridization and DNA base composition. For hybridization experiments, genomic DNA of strain EDIV ${ }^{\mathrm{T}}$ and $S$. trueperi ATCC $12417^{\mathrm{T}}$ was isolated by hydroxyapatite chromatography by the procedure of Cashion et al. (1977). DNA-DNA hybridization was determined spectrophotometrically, as described by De Ley et al. (1970), with modifications as described by Huss et al. (1983) and Escara \& Hutton (1980), using a Gilford System model 2600 spectrophotometer equipped with a Gilford model 2527-R thermoprogrammer and plotter. Renaturation rates were computed with the TRANSFER.BAS program (Jahnke, 1992). These experiments were carried out by the Identification Service of the DSMZ, Braunschweig, Germany. For determination of the DNA base composition, DNA was extracted by the method of Marmur (1961). The mean $\mathrm{G}+\mathrm{C}$ content $(\mathrm{mol} \%)$ of the genomic DNA was determined by HPLC (Tamaoka \& Komagata, 1984; Kaneko et al., 1986) after nuclease $\mathrm{P}_{1}$ and alkaline phosphatase treatment.

Production, extraction, deacetylation and hydrolysis of the exopolysaccharide. For production of the exopolysaccharide, strain $\mathrm{EDIV}^{\mathrm{T}}$ was cultivated for $5 \mathrm{~d}$ at $28-30{ }^{\circ} \mathrm{C}$ with rotary shaking (500 r.p.m.) in 1 litre Erlenmeyer flasks containing $300 \mathrm{ml}$ of a mineral salt medium containing the following $\left(1^{-1}\right.$ deionized water; $\left.\mathrm{pH} 7 \cdot 3 \pm 0 \cdot 2\right): 1 \cdot 0 \mathrm{~g} \mathrm{~K}_{2} \mathrm{HPO}_{4}$, $0.5 \mathrm{~g} \mathrm{KCl}_{0} 0.01 \mathrm{~g} \mathrm{Fe}_{2}\left(\mathrm{SO}_{4}\right)_{3}, 0.5 \mathrm{~g} \mathrm{MgSO}_{4} .7 \mathrm{H}_{2} \mathrm{O}$ and $3.0 \mathrm{~g}$ $\mathrm{NaNO}_{3}$, supplemented with $12 \%$ (w/v) sucrose. Subsequently, the extracellular material was precipitated with 3 vols 1-propanol, as described by Azeredo \& Olivera (1996), after dilution $(1: 10)$ of the highly viscous broth and centrifugation at $9000 \mathrm{~g}$ for $30 \mathrm{~min}$ to remove cells. The precipitate was washed with propane three times and then lyophilized. Deacylation was performed, as described by Kang et al. (1982), and the deacetylated exopolysaccharide was precipitated with 2 vols 1-propanol and dried by lyophilization. For compositional analysis, the native, as well as the deacetylated, exopolysaccharides were hydrolysed with trifluoroacetic acid as described previously (Hashimoto \& Murato, 1998). The remaining hydrolysed exopolysaccharide was dissolved in HPLC-grade water (Merck), after evaporation of the trifluoroacetic acid under a vacuum at room temperature, and stored at $-20^{\circ} \mathrm{C}$.

Exopolysaccharide component analysis. The monosaccharides of the hydrolysed exopolysaccharide were separated by TLC on silica-gel $\mathrm{F}_{254}$ plates (Merck). Acetone/butanol/water (40:5:5, by vol.) and butanol/ acetic acid/water (4:6:1, by vol.) were used as solvent systems; $1-2 \mu$ of the hydrolysate was applied to the TLC plate. Typical components of exopolysaccharides produced by sphingomonads (Pollock, 1993), including glucose, rhamnose, mannose and glucuronic acid, were used as references. The individual components were detected by heating the TLC plates at $110^{\circ} \mathrm{C}$ for $5 \mathrm{~min}$ after spraying them with $10 \%(\mathrm{v} / \mathrm{v})$ sulfuric acid in ethanol (Hashimoto \& Murato, 1998) and $\alpha$-naphthol (Jacin \& Mishkin, 1965). Additionally, hydrolysates, as well as the reference sugars (glucose, rhamnose, mannose and glucuronic acid), were separated by HPLC with an Aminex HPX87-H column, with 0.025 M $\mathrm{H}_{2} \mathrm{SO}_{4}$ as the eluant, at an operating temperature of $60^{\circ} \mathrm{C}$ and a flow rate of $0.5 \mathrm{ml} \mathrm{min} \mathrm{m}^{-1}$. A $20 \mu$ laliquot of pre-filtered sample was injected and the components were detected by a refractive index detector (RID-10A). Monomeric sugars were identified on the basis of their retention times, using reference sugars (Sigma). The molecular mass of the exopolysaccharide was determined by gel-permeation chromatography, using a Nucleogel aqua-OH 60-8 column (Macherey-Nagel) with a pore size of $4000 \AA$, an exclusion size of $20 \mathrm{MDa}$ and $0.02 \%$ sodium azide in water as the mobile phase. The eluent was detected by a light-scatter detector. The presence of monomeric uronic acids and sulfate esters was determined by FT-IR spectroscopy (Ishizuka et al., 1973). The monomeric uronic acid content was also determined by GC-MS and the characteristic fragmentation pattern of the uronic methyl esters.

\section{RESULTS}

\section{Phenotypic characteristics}

Initially, when strain EDIV $^{\mathrm{T}}$ was isolated from CZD agar (containing sucrose as the major carbon and energy source), copious amounts of an extracellular material were produced, resulting in colonies with a slimy/viscous, intensely yellow appearance. Culture fluids of the liquid version of CZD medium were highly viscous after $5 \mathrm{~d}$ cultivation.

Cells of strain EDIV ${ }^{\mathrm{T}}$ were straight rods $(0 \cdot 4-0 \cdot 75 \mu \mathrm{m}$ wide by $1 \cdot 0-3 \cdot 0 \mu \mathrm{m}$ long) that were Gram-negative and motile by means of a single polar flagellum. After some exopolysaccharide had been produced, the cells in older cultures became slow-moving or were nonmotile. Endospores were not observed under any of the growth conditions applied. Electron microscope examination of ultrathin sections demonstrated that the cell envelopes were typical of Gram-negative bacteria, there being a cytoplasmic membrane and an outer membrane (Fig. 1a); inclusion bodies containing storage material (probably polyphosphate and PHB) were also observed (Fig. 1b). GC analyses confirmed the presence of PHB in the cells. Colonies grown on complex peptone-containing standard media were as large as $1 \mathrm{~mm}$ in diameter, circular, entire, convex, smooth and deep-yellow as a result of a non-diffusible pigment after $48 \mathrm{~h}$ incubation at $28-30{ }^{\circ} \mathrm{C}$. Good growth was also observed on the low-nutrient medium R2A (Reasoner \& Geldreich, 1985). Colonies were $1.5 \mathrm{~mm}$ in diameter, translucent, yellow, circular, entire, low-convex and smooth on R2A agar after $2 \mathrm{~d}$. No growth was observed on any media tested at 4, 37 or $45^{\circ} \mathrm{C}$.

Characterization tests, performed according to conventional methods, showed strain EDIV $^{\mathrm{T}}$ to be catalase-positive, oxidase-negative, strictly aerobic and non-fermentative. It was unable to reduce nitrate, was indole-negative and did not form $\mathrm{H}_{2} \mathrm{~S}$. Tween 80 was hydrolysed, but starch, gelatin, casein and DNA were not. By using the API 20NE identification system, 

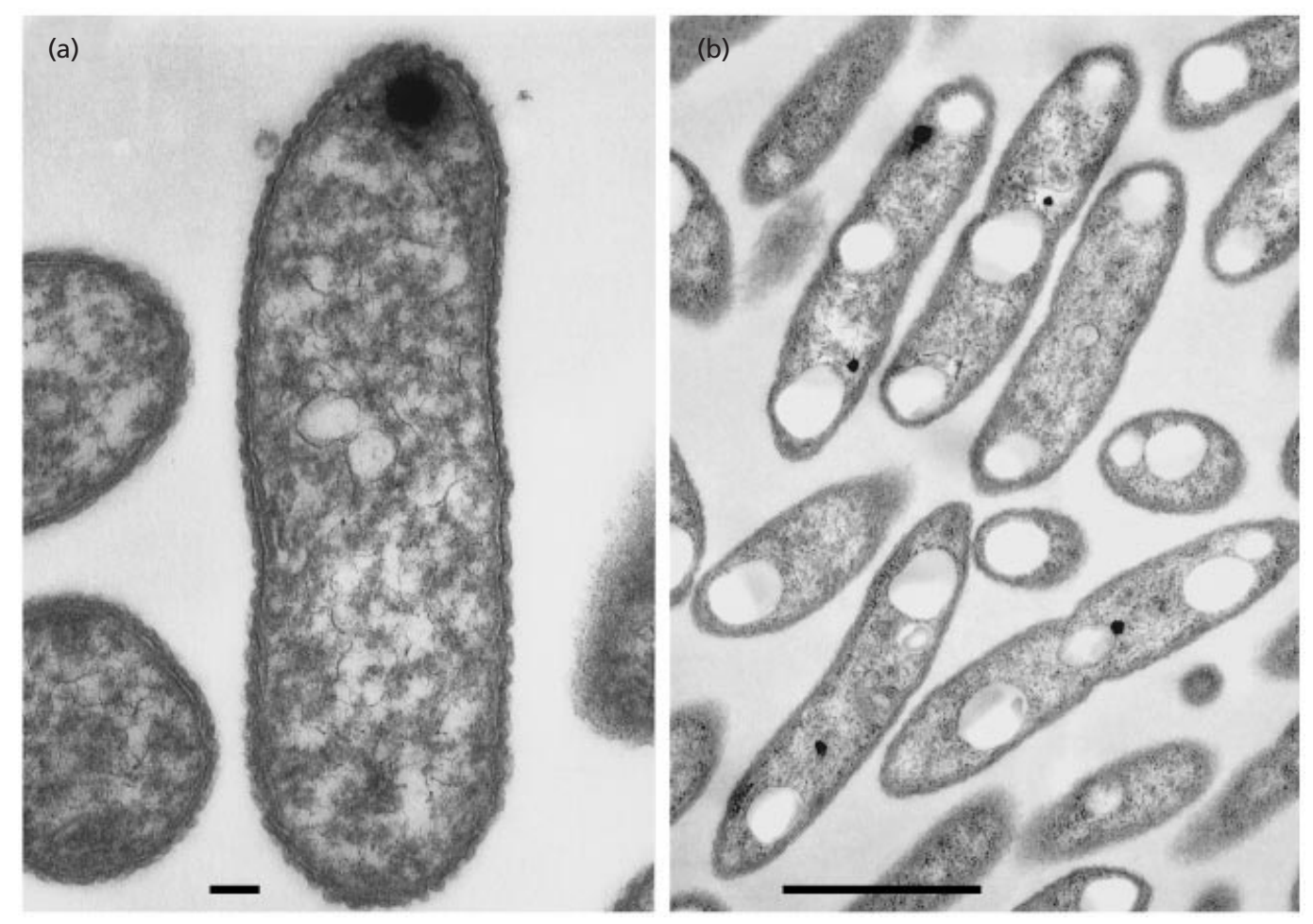

Fig. 1. Electron micrographs of ultrathin sections of strain EDIV ${ }^{\top}$. (a) Gram-negative cell wall structure of the bacterium. Bar, $100 \mathrm{~nm}$. (b) The presence of polyphosphate (black) and large PHB inclusion bodies (white) in cells grown for $5 \mathrm{~d}$ in a mineral salt medium containing $12 \%(\mathrm{w} / \mathrm{v})$ sucrose. Bar, $500 \mathrm{~nm}$.

strain EDIV $^{\mathrm{T}}$ was identified, with $99 \cdot 8 \%$ (API code 0463340) probability, as $S$. paucimobilis. Strain EDIV ${ }^{\mathrm{T}}$ formed deep-yellow colonies on agar plates. The spectral characteristics of the yellow pigment extracted in acetone $\left(\lambda_{\max }\right.$ at 452 and $478 \mathrm{~nm}$ and a slight inflexion at $425 \mathrm{~nm}$ ) corresponded to those reported for the carotenoid nostoxanthin $\left[\left(2 \mathrm{R}, 3 \mathrm{r}, 2^{\prime} \mathrm{R}, 3 \mathrm{R}\right)-\beta, \beta\right.$ carotene-2,3,2',3'-tetrol]. Nostoxanthin was identified by Jenkins et al. (1979) as the yellow pigment of [Pseudomonas] paucimobilis (now S. paucimobilis) and was also detected in 'Pseudomonas azotocolligans' (now $S$. trueperi) and [Pseudomonas] echinoides (now S. echinoides).

Antibiotic-susceptibility tests revealed that strain EDIV $^{\mathrm{T}}$ is sensitive to ampicillin, chloramphenicol, gentamicin, kanamycin and tetracycline and resistant to penicillin $G$, polymyxin B and streptomycin. The type strain of $S$. paucimobilis displayed the same susceptibility pattern, except that the strain was resistant to ampicillin and tetracycline. S. trueperi ATCC $12417^{\mathrm{T}}$ exhibited an antibiotic-susceptibility pattern identical to that of strain EDIV $^{\mathrm{T}}$.

The results obtained from further biochemical testing indicated that strain EDIV ${ }^{\mathrm{T}}$ is different from $S$. paucimobilis and is, furthermore, clearly separable from other species within the $S$. paucimobilis branch. A detailed comparison was made between these results and all previously published biochemical data (Heumann, 1962; Yabuuchi et al., 1990; Takeuchi et al., 1993; Kämpfer et al., 1997; Denner et al., 1999; Yun et al., 2000), as shown in Table 1.

\section{Chemotaxonomic characteristics}

Ubiquinone Q-10 was determined to be the major respiratory lipoquinone system in strain $\mathrm{EDIV}^{\mathrm{T}}$. The predominant cellular fatty acids (Table 2) were included in summed feature $7(18: 1 \omega 7 c, 18: 1 \omega 9 t$ and/or 18:1 $\omega 12 t)$. Other significant fatty acids were 14:0 2-OH, 17:1 $\omega 6 c, 16: 0,15: 0$ and 15:0 2-OH. 3Hydroxy fatty acids were not detected. The triamine sym-homospermidine $\left(68.4 \mu \mathrm{mol} \mathrm{g}^{-1}\right.$, dry weight $)$ was observed to be the major component in the polyamine pattern, with minor amounts of spermidine $\left(3.3 \mu \mathrm{mol} \mathrm{g}^{-1}\right.$, dry weight $)$ and spermine $\left(1.0 \mu \mathrm{mol} \mathrm{g}{ }^{-1}\right.$, dry weight) being detected as well. The overall polar lipid pattern was characterized by the presence of phosphatidylethanolamine, phosphatidyldimethylethanolamine, phosphatidylglycerol, sphingoglycolipid and an unidentified lipid (L1) as major compounds. Minor amounts of diphosphatidylglycerol, phosphatidylmonomethylethanolamine, phosphatidylcholine and several unknown lipids were detected as well. The total polar lipid content of 
Table 1. Comparative biochemical characteristics of strain EDIV ${ }^{\top}$ and type strains of species of the $S$. paucimobilis branch

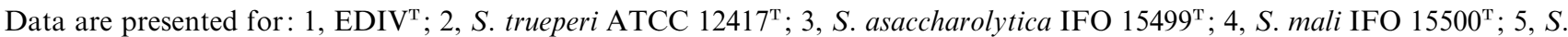

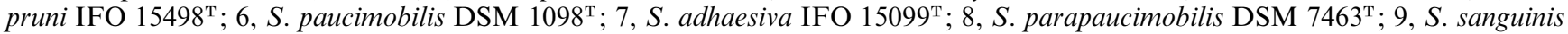

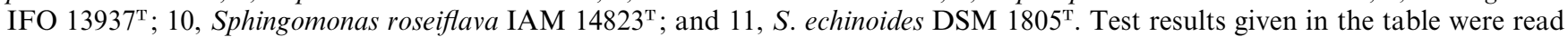
after $72 \mathrm{~h}$ incubation at $30^{\circ} \mathrm{C}$. Results are scored as: + , positive; - , negative; $(+)$, weakly positive; ND, no data. pNA, paraNitroanilide; pNP, para-nitrophenyl. Strain EDIV ${ }^{\mathrm{T}}$ and all other strains gave positive results in the following tests: catalase activity; hydrolysis of bis-pNP phosphate, pNP phenyl-phosphate, 2-deoxythymidine-5'-pNP phosphate, L-alanine-pNA and Lglutamate- $\gamma$-3-carboxy-pNA; assimilation of $N$-acetylglucosamine, cellobiose, D-galactose, glucose, maltose and D-trehalose. All of the strains gave negative results for acid production from lactose, sucrose, dulcitol, adonitol, L-arabinose, raffinose and D-arabitol and for the assimilation of D-ribose, adonitol, $i$-inositol, D-mannitol, D-sorbitol, putrescine, 4-aminobutyrate, azelate, itaconate, mesaconate, $\beta$-alanine, L-phenylalanine, L-tryptophan, 3-hydroxybenzoate and phenylacetate. Data in columns $2-9$ were taken from Yabuuchi et al. (1990), Takeuchi et al. (1993), Kämpfer et al. (1997) and this study. Data in column 10 were taken from Yun et al. (2000). Data in column 11 were taken from Heumann (1962), Denner et al. (1999) and this study.

\begin{tabular}{|c|c|c|c|c|c|c|c|c|c|c|c|}
\hline Characteristic & 1 & 2 & 3 & 4 & 5 & 6 & 7 & 8 & 9 & 10 & 11 \\
\hline Nitrate reduction & - & - & - & - & - & - & - & + & - & + & + \\
\hline DNase production & - & - & - & - & - & + & + & + & + & + & - \\
\hline Liquefaction of gelatin & - & - & - & - & - & + & - & - & + & + & - \\
\hline \multicolumn{12}{|l|}{ Acid produced from:* } \\
\hline Glucose & $(+)$ & - & $(+)$ & $(+)$ & $(+)$ & - & - & - & - & ND & - \\
\hline D-Mannitol & - & - & + & - & - & - & - & - & - & ND & - \\
\hline Salicin & - & - & $(+)$ & - & - & + & + & - & - & ND & - \\
\hline Inositol & - & - & + & - & - & - & - & - & - & ND & - \\
\hline Sorbitol & - & + & - & - & - & - & - & - & - & ND & - \\
\hline Rhamnose & $(+)$ & - & $(+)$ & - & - & - & $(+)$ & $(+)$ & - & ND & - \\
\hline Maltose & $(+)$ & - & - & - & - & $(+)$ & $(+)$ & $(+)$ & - & ND & - \\
\hline D-Xylose & $(+)$ & - & - & - & - & + & $(+)$ & $(+)$ & - & ND & - \\
\hline Trehalose & - & - & + & - & - & - & - & - & - & $\mathrm{ND}$ & - \\
\hline Cellobiose & $(+)$ & - & - & - & - & $(+)$ & $(+)$ & $(+)$ & - & ND & - \\
\hline Methyl $\alpha$-D-glucoside & - & + & - & - & - & + & + & - & - & ND & - \\
\hline Erythritol & - & - & - & - & - & - & + & - & - & ND & - \\
\hline Melibiose & - & - & - & - & - & $(+)$ & $(+)$ & $(+)$ & - & ND & - \\
\hline D-Mannose & - & - & - & - & - & $(+)$ & $(+)$ & $(+)$ & - & ND & - \\
\hline \multicolumn{12}{|l|}{ Hydrolysis of: } \\
\hline Aesculin & + & - & - & $(+)$ & $(+)$ & $(+)$ & - & $(+)$ & - & + & + \\
\hline pNP Galactopyranoside & + & + & $(+)$ & + & $(+)$ & + & $(+)$ & + & + & ND & - \\
\hline $\mathrm{pNP} \beta$-D-Glucuronide & + & + & + & + & + & - & + & + & + & ND & + \\
\hline pNP Phosphorylcholine & + & + & + & + & + & - & + & + & + & ND & + \\
\hline L-Glutamate- $\gamma-3$-carboxy-pNA & + & + & + & + & + & + & + & + & + & ND & $(+)$ \\
\hline L-Proline-pNA & - & - & + & + & + & - & - & + & - & ND & + \\
\hline \multicolumn{12}{|l|}{ Assimilation of: } \\
\hline L-Arabinose & + & + & + & + & + & + & - & + & + & + & + \\
\hline$p$-Arbutin & + & + & - & + & + & + & + & + & + & $\mathrm{ND}$ & - \\
\hline D-Fructose & - & + & - & - & - & - & + & - & + & ND & - \\
\hline Gluconate & - & - & - & + & - & - & - & + & - & + & - \\
\hline D-Mannose & + & + & + & + & + & + & + & + & + & $(+)$ & - \\
\hline$\alpha$-D-Melibiose & + & + & + & + & + & - & + & + & + & $\mathrm{ND}$ & - \\
\hline L-Rhamnose & - & - & + & + & + & - & - & $(+)$ & - & ND & - \\
\hline Sucrose & + & + & $(+)$ & + & + & + & + & + & + & ND & - \\
\hline Salicin & + & + & $(+)$ & + & $(+)$ & - & + & + & + & ND & - \\
\hline D-Xylose & + & + & $(+)$ & + & + & + & - & + & + & ND & - \\
\hline Maltitol & - & + & + & - & - & - & - & - & + & ND & - \\
\hline Acetate & + & + & - & - & - & - & - & + & + & ND & - \\
\hline Propionate & - & + & - & - & - & - & - & + & + & ND & - \\
\hline cis-Aconitate & - & - & - & - & - & + & - & + & - & ND & - \\
\hline trans-Aconitate & - & - & - & - & - & + & - & - & - & $\mathrm{ND}$ & - \\
\hline Adipate & - & - & - & $(+)$ & - & - & - & - & - & $(+)$ & - \\
\hline
\end{tabular}


Table 1 (cont.)

\begin{tabular}{|c|c|c|c|c|c|c|c|c|c|c|c|}
\hline Characteristic & 1 & 2 & 3 & 4 & 5 & 6 & 7 & 8 & 9 & 10 & 11 \\
\hline Citrate & - & - & - & - & - & - & - & + & - & + & - \\
\hline Fumarate & + & + & $(+)$ & + & + & + & + & - & + & ND & + \\
\hline Glutarate & - & + & - & - & - & - & - & + & - & ND & - \\
\hline DL-3-Hydroxybutyrate & + & + & + & + & + & - & - & + & + & ND & - \\
\hline DL-Lactate & - & + & - & - & - & - & - & + & + & ND & - \\
\hline L-Malate & + & + & - & - & - & + & + & + & + & + & + \\
\hline Oxoglutarate & - & - & - & - & - & + & + & + & + & ND & - \\
\hline Pyruvate & + & + & - & + & - & + & - & + & + & ND & - \\
\hline Suberate & - & - & - & + & - & - & + & - & - & ND & - \\
\hline L-Alanine & + & + & + & - & - & - & + & + & + & ND & - \\
\hline L-Asparate & - & + & + & + & + & - & + & - & + & ND & - \\
\hline L-Histidine & - & - & - & + & + & - & - & - & - & ND & - \\
\hline L-Leucine & - & + & - & - & - & - & + & + & + & ND & - \\
\hline L-Ornithine & - & - & - & - & - & - & - & - & + & ND & - \\
\hline L-Proline & + & - & + & - & - & - & + & - & + & ND & - \\
\hline L-Serine & - & + & - & - & - & - & - & - & - & ND & - \\
\hline 4-Hydroxybenzoate & - & + & - & - & - & - & - & - & - & ND & - \\
\hline
\end{tabular}

* Acid production from carbohydrates by strain EDIV ${ }^{\mathrm{T}}$ was very weak (even after prolonged incubation), as reported for other Sphingomonas species (Kämpfer et al., 1997; Denner et al., 1999); therefore these tests cannot be recommended for differentiation.

Table 2. Major fatty acid composition of strain EDIV ${ }^{\top}$ and selected type strains of species of the $S$. paucimobilis branch

Data are presented for: 1 , EDIV ${ }^{\mathrm{T}} ; 2$, S. trueperi ATCC $12417^{\mathrm{T}} ; 3$, S. asaccharolytica IFO $15499^{\mathrm{T}} ; 4$, S. mali IFO $15500^{\mathrm{T}} ; 5$, S. pruni IFO $15498^{\mathrm{T}} ; 6$, S. paucimobilis DSM 1098 ${ }^{\mathrm{T}} ; 7, S$. adhaesiva IFO $15099^{\mathrm{T}} ; 8$, S. parapaucimobilis DSM 7463 ${ }^{\mathrm{T}}$; 9, S. sanguinis IFO $13937^{\mathrm{T}} ; 10, S$. echinoides DSM $1805^{\mathrm{T}}$. Values are percentages of total fatty acid. Fatty acid nomenclature: for unsaturated fatty acids, the position of the double bond can be located by counting from the methyl $(\omega)$ end of the carbon chain. cis is indicated by the suffix $c$. Summed features represent groups of two or three fatty acids that could not be separated by GLC with the MIDI system (Microbial ID). Summed feature 4 contained one or more of the following fatty acids: $16: 1 \omega 7$ and 15:0 iso 2-OH. Summed feature 7 contained one or more of the following isomers: $18: 1 \omega 7 c$, 18:1 $\omega 9 t$ and/or 18:1 $\omega 12 t$ (cis and trans isomers are indicated by the suffixes $c$ and $t$, respectively). Data in columns 2-9 were from Kämpfer et al. (1997). Data in column 10 were from Denner et al. (1999).

\begin{tabular}{|lcccccccccc|}
\hline Compound & $\mathbf{1}$ & $\mathbf{2}$ & $\mathbf{3}$ & $\mathbf{4}$ & $\mathbf{5}$ & $\mathbf{6}$ & $\mathbf{7}$ & $\mathbf{8}$ & $\mathbf{9}$ & $\mathbf{1 0}$ \\
\hline Saturated fatty acids: & & & & & & & & & & \\
$14: 0$ & - & - & - & - & - & $1 \cdot 4$ & - & $1 \cdot 0$ & $1 \cdot 0$ & $0 \cdot 9$ \\
$15: 0$ & $2 \cdot 6$ & - & - & - & - & - & - & - & $1 \cdot 1$ & - \\
$16: 0$ & $11 \cdot 5$ & $9 \cdot 8$ & $13 \cdot 3$ & $11 \cdot 8$ & $16 \cdot 0$ & $8 \cdot 7$ & $6 \cdot 5$ & $9 \cdot 6$ & $13 \cdot 6$ & $10 \cdot 0$ \\
$17: 0$ & - & $1 \cdot 6$ & - & - & - & - & - & - & $0 \cdot 5$ & - \\
$18: 0$ & - & - & - & - & - & - & - & - & $0 \cdot 6$ & - \\
Unsaturated fatty acids: & & & & & & & & & & \\
$16: 1 \omega 5 c$ & - & - & - & - & - & - & - & $1 \cdot 9$ & $1 \cdot 0$ & $0 \cdot 8$ \\
$17: 1 \omega 6 c$ & $13 \cdot 0$ & $13 \cdot 6$ & - & $9 \cdot 3$ & - & $3 \cdot 0$ & $21 \cdot 2$ & $3 \cdot 8$ & $2 \cdot 4$ & $2 \cdot 9$ \\
$17: 1 \omega 8 c$ & - & - & - & - & - & - & - & - & - & - \\
$18: 1 \omega 5 c$ & - & $4 \cdot 0$ & - & - & - & $3 \cdot 2$ & - & $3 \cdot 5$ & $3 \cdot 5$ & $2 \cdot 7$ \\
Hydroxy fatty acids: & & & & & & & & & & \\
$14: 0$ 2-OH & $14 \cdot 2$ & $6 \cdot 7$ & $18 \cdot 8$ & $8 \cdot 4$ & $10 \cdot 9$ & $6 \cdot 4$ & $13 \cdot 8$ & $6 \cdot 7$ & $5 \cdot 0$ & $7 \cdot 2$ \\
$15: 0$ 2-OH & $2 \cdot 4$ & - & - & - & - & - & - & - & - & - \\
$16: 0$ 2-OH & - & - & - & - & - & - & - & - & - & - \\
Summed feature 4 & $2 \cdot 1$ & - & - & - & - & $2 \cdot 7$ & $6 \cdot 2$ & $8 \cdot 6$ & $6 \cdot 7$ & $2 \cdot 45$ \\
Summed feature 7 & $54 \cdot 2$ & $64 \cdot 2$ & $67 \cdot 8$ & $70 \cdot 5$ & $73 \cdot 1$ & $74 \cdot 6$ & $47 \cdot 3$ & $65 \cdot 0$ & $64 \cdot 6$ & $73 \cdot 1$ \\
\hline
\end{tabular}




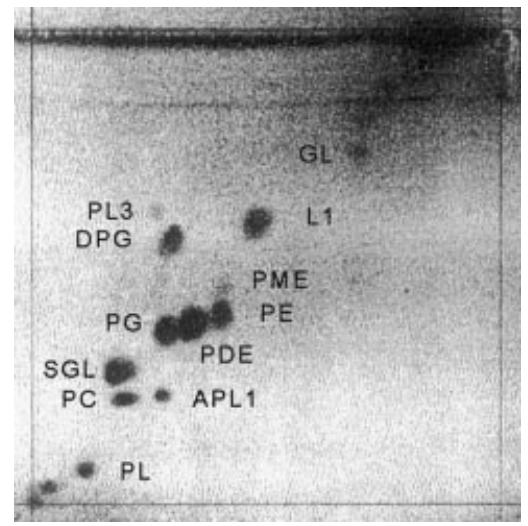

Fig. 2. Polar lipids of strain $E{ }^{\prime} V^{\top}$ after separation by twodimensional TLC. Major lipids: DPG, diphosphatidylglycerol; $\mathrm{PE}$, phosphatidylethanolamine; $\mathrm{PDE}$, phosphatidyldimethylethanolamine; PG, phosphatidylglycerol; SGL, sphingoglycolipid; L1, unidentified polar lipid. Minor lipids: PC, phosphatidylcholine; PME, phosphatidylmonomethylethanolamine; APL1, unidentified aminophospholipid; PL and PL3, unknown phospholipids; GL, unknown glycolipid. The TLC plate was sprayed with molybdatophosphoric acid.

EDIV $^{\mathrm{T}}$ after separation by two-dimensional TLC is shown in Fig. 2.

The combination of these chemotaxonomic features is consistent with the current description of the genus Sphingomonas and confirms the results of other studies (Takeuchi et al., 1993, 1995; Kämpfer et al., 1997; Denner et al., 1999; Busse et al., 1999).

\section{$16 \mathrm{~S}$ rRNA gene sequence and phylogenetic inferences}

PCR amplification and direct sequencing allowed the determination of 1446 nucleotide positions of the $16 \mathrm{~S}$ rRNA gene sequence of strain EDIV ${ }^{\mathrm{T}}$ (approx. 97\% of the complete gene, as estimated by comparison with the 16S rRNA gene sequence of $E$. coli). The nearly complete 16S rRNA gene sequence determined in this study has been deposited in the EMBL database (Stoesser et al., 1999). The 16S rRNA gene sequence of strain EDIV ${ }^{\mathrm{T}}$ is seen to be clustered within those of the species of Sphingomonas (Fig. 3), most closely related ( $99 \cdot 4 \%$ similarity) to $S$. trueperi LMG $2142^{\mathrm{T}}$ (formerly 'Pseudomonas azotocolligans' Anderson 1955) (Kämpfer et al., 1997). Similarities between the 16S rRNA gene sequences of strain $\mathrm{EDIV}^{\mathrm{T}}$ and the other validly described species of Sphingomonas (Table 3) ranged from $96.3 \%$ (with Sphingomonas asaccharolytica IFO $15099^{\mathrm{T}}$ ) to $90.8 \%$ (with Sphingomonas terrae IFO $15098^{\mathrm{T}}$ ). A $16 \mathrm{~S}$ rRNA gene sequence similarity of $99.4 \%$ clearly indicates that $\mathrm{EDIV}^{\mathrm{T}}$ and $S$. trueperi are closely related phylogenetically, but it does not allow the confident assertion that the two organisms should be considered as a single species (Fox et al., 1992). The next most closely related organisms include those of the S. paucimobilis lineage, giving $16 \mathrm{~S}$ rRNA gene sequence similarities of approximately $96 \%$, a level that clearly delineates different species. Fig. 3 is a dendrogram of estimated phylogenetic relationships inferred from comparisons and evolutionary distance calculations that were derived from 1387 nucleotide positions between positions 28 and 1465 (E. coli numbering) from the 16S rRNA gene sequences of strain EDIV $^{\mathrm{T}}$ and all validly published species of Sphingomonas and other related species of the $\alpha-4$ subclass of the Proteobacteria. The inferred phylogenetic relationships indicated a clear delineation of the $\mathrm{EDIV}^{\mathrm{T}} / S$. trueperi branch from all other Sphingomonas species. A bootstrap confidence level of $100 \%$ (Felsenstein, 1985) (derived from analysis of 500 resamplings) was observed for the $\mathrm{EDIV}^{\mathrm{T}} / S$. trueperi delineation. The topography of the dendrogram was also tested by using a treeing algorithm of maximumlikelihood (fastDNAmL, version 1.0; Maidak et al., 1996). This alternative analysis supported most branching points defined by the distance analysis, including the distinct delineation and branching order of the EDIV ${ }^{\mathrm{T}} / S$. trueperi lineage among the species of the $S$. paucimobilis branch (data not shown).

\section{DNA-DNA hybridization analysis and DNA base composition}

In view of the high level of $16 \mathrm{~S}$ rRNA gene sequence similarity observed between strain EDIV $^{\mathrm{T}}$ and $S$. trueperi LMG $2142^{\mathrm{T}}$, a DNA-DNA hybridization analysis was performed between EDIV $^{\mathrm{T}}$ and the reference type strain, ATCC $12417^{\mathrm{T}}$ (= LMG $2142^{\mathrm{T}}$ ). The level of DNA relatedness observed between the two strains was $45.5 \%$, suggesting that $\mathrm{EDIV}^{\mathrm{T}}$ and $S$. trueperi ATCC $12417^{\mathrm{T}}$ (= LMG $2142^{\mathrm{T}}$ ) do not belong to the same species. The DNA $\mathrm{G}+\mathrm{C}$ content of $\operatorname{EDIV}^{\mathrm{T}}(64.5 \mathrm{~mol} \%)$ was well within the range of values $(61 \cdot 6-67 \cdot 8 \mathrm{~mol} \%)$ reported for established Sphingomonas species.

\section{SDS-PAGE analysis of whole-cell proteins and FT-IR spectra of whole-cell preparations}

Comparison of the whole-cell protein patterns of strains EDIV ${ }^{\mathrm{T}}$ and $S$. trueperi ATCC $12417^{\mathrm{T}}$ following separation by SDS-PAGE, a method that is used widely in bacterial systematics as an alternative to biotyping methods for strain and species differentiation (e.g. Owen \& Jackman, 1982; Jackman, 1987; Vauterin et al., 1993), showed that EDIV ${ }^{\mathrm{T}}$ differed markedly from ATCC $12417^{\mathrm{T}}$. In addition, FT-IR spectra of bacteria, recorded from whole cells without any preparation other than drying, provide fingerprint-like, highly reproducible patterns that distinguish strains at the subspecies level (e.g. Helm et al., 1991a, b; Naumann et al., 1991; Raguenes et al., 1996; Huu et al., 1999). The FT-IR spectra obtained from strains EDIV ${ }^{\mathrm{T}}$ and ATCC $12417^{\mathrm{T}}$ indicated differences in prominent, additional peaks or peak shoulders between wave numbers 1200 and 900 (data not shown); 


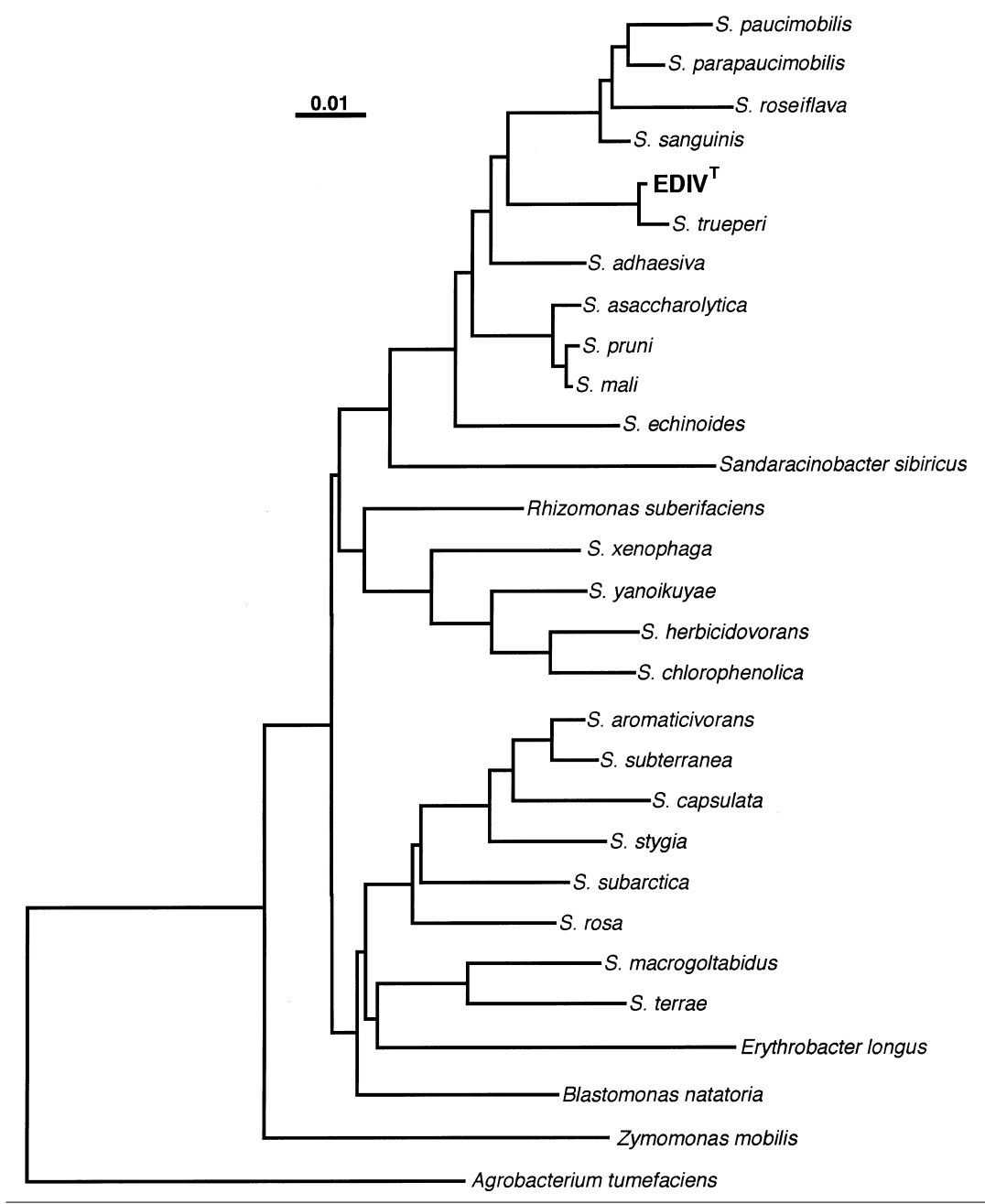

Fig. 3. Phylogenetic dendrogram based on 16S rRNA gene sequence data, indicating the position of strain $\mathrm{EDIV}^{\top}$ within the radiation of the $\alpha-4$ subclass of the Proteobacteria, as derived by evolutionary distance calculations of pairwise comparisons of nearly complete 16S rRNA gene sequences, including the correction factor of Jukes \& Cantor (1969). The dendrogram was generated by the least-squares distance algorithm of the FITCH program in PHYLIP. Agrobacterium tumefaciens was used as the outgroup. The bar represents estimated evolutionary distance (a mean of 1 substitution at any nucleotide position per 100 nucleotide positions). S., Sphingomonas.

this window represents the polysaccharide region (Helm et al., 1991a).

\section{Component analysis of the exopolysaccharide}

The extracellular material secreted by strain EDIV ${ }^{\mathrm{T}}$ was found, upon hydrolysis and paper chromatography, to contain rhamnose and glucose, as well as an unidentified sugar. The mean molecular mass, as determined by gel-permeation chromatography, was approximately $3 \times 10^{6} \mathrm{Da}$. No uronic acids or sulfates could be detected using the methods applied, setting the upper limit of these glycosides to $3 \%$ of the total glycosidic content within the exopolysaccharide.

\section{DISCUSSION}

The comprehensive polyphasic taxonomic study presented here provides clear evidence for the classification of the exopolysaccharide-producing bacterial strain EDIV ${ }^{\mathrm{T}}$ as a new species of the genus Sphingomonas.

The genus Sphingomonas (Yabuuchi et al., 1990) is a heterogeneous taxon as it is currently described, and can be divided into several phylogenetic branches within the $\alpha-4$ subclass of the Proteobacteria together with the genera Blastomonas, Rhizomonas, Zymomonas and several aerobic, bacteriochlorophyll- $a$ containing genera on the basis of 16S rRNA gene sequence comparisons (Van Bruggen et al., 1993; Segers et al., 1994; Takeuchi et al., 1994, 1995, 1999; Balkwill et al., 1997; Hiraishi et al., 2000). The range of 16S rRNA gene sequence dissimilarities between the species of the genus Sphingomonas is much too large for all described species to be included within one genus. The estimated breadth of phylogenetic relationships demonstrates clearly that a number of Sphingomonas species should be described as distinct, new genera and that the species of the $S$. paucimobilis branch should be considered as the genus Sphingomonas sensu stricto, as suggested by Takeuchi et al. (1995, 1999), including, at present, the species S. paucimobilis, S. parapaucimobilis, S. sanguinis, $S$. trueperi, $S$. adhaesiva, S. pruni, S. mali, $S$. asaccharolytica and S. echinoides. Interestingly, species of the $S$. paucimobilis branch share the characteristic sym-homospermidine as the major compound in the polyamine pattern (Busse et al., 1999). In contrast, all 
Table 3. Sequence similarities between the $16 \mathrm{~S}$ rRNA genes of strain $\mathrm{EDIV}^{\top}$ and members of the genus Sphingomonas and other species of the $\alpha$-subclass of the Proteobacteria

Culture collections are abbreviated as: ATCC, American Type Culture Collection, Manassas, VA, USA; DSM, Deutsche Sammlung von Mikroorganismen und Zellkulturen, Braunschweig, Germany; HAMBI, Culture Collection of the Faculty of Agriculture and Forestry, University of Helsinki, Helsinki, Finland; IAM, Institute of Applied Microbiology, University of Tokyo, Bunkyo-ko, Tokyo, Japan; IFO, Institute for Fermentation, Yodogawa-ku, Osaka, Japan; JCM, Japan Collection of Microorganisms, Wako, Saitama, Japan; LMG, Laboratorium voor Microbiologie, Universiteit Gent, Gent, Belgium; SMCC, Subsurface Microbial Culture Collection, Florida State University, Tallahassee, FL, USA.

\begin{tabular}{|c|c|c|c|}
\hline Species & Strain & $\begin{array}{c}\text { EMBL } \\
\text { accession no. }\end{array}$ & $\begin{array}{l}\text { Sequence similarity to } \\
\text { strain } \operatorname{EDIV}^{\mathrm{T}}(\%)\end{array}$ \\
\hline S. trueperi & LMG $2142^{\mathrm{T}}$ & X97776 & $99 \cdot 4$ \\
\hline S. asaccharolytica & IFO $15499^{\mathrm{T}}$ & Y09639 & $96 \cdot 3$ \\
\hline S. mali & IFO $15500^{\mathrm{T}}$ & Y09638 & $96 \cdot 2$ \\
\hline S. pruni & IFO $15498^{\mathrm{T}}$ & Y09637 & $96 \cdot 2$ \\
\hline S. paucimobilis & DSM $1089^{\mathrm{T}}$ & X72722 & $96 \cdot 0$ \\
\hline S. adhaesiva & JCM $7370^{\mathrm{T}}$ & $\mathrm{X} 72720$ & $95 \cdot 8$ \\
\hline S. parapaucimobilis & JCM $7510^{\mathrm{T}}$ & X72721 & $95 \cdot 7$ \\
\hline S. sanguinis & IFO $13937^{\mathrm{T}}$ & D13726 & $95 \cdot 5$ \\
\hline S. roseiflava & IAM $14823^{\mathrm{T}}$ & D84520 & $94 \cdot 9$ \\
\hline S. echinoides & DSM $1805^{\mathrm{T}}$ & AJ012461 & $94 \cdot 2$ \\
\hline S. xenophaga & DSM $6383^{\mathrm{T}}$ & X94098 & $92 \cdot 9$ \\
\hline Rhizomonas suberifaciens & IFO $15211^{\mathrm{T}}$ & D13737 & $92 \cdot 8$ \\
\hline S. yanoikuyae & $\mathrm{JCM} 7371^{\mathrm{T}}$ & $X 72725$ & $92 \cdot 6$ \\
\hline S. aromaticivorans & SMCC F199"T & U20756 & $92 \cdot 5$ \\
\hline S. rosa & IFO $15208^{\mathrm{T}}$ & D13945 & $92 \cdot 5$ \\
\hline S. chlorophenolica & ATCC $33790^{\mathrm{T}}$ & X87161 & $92 \cdot 4$ \\
\hline S. stygia & $\mathrm{SMCC} \mathrm{B} 0712^{\mathrm{T}}$ & U20775 & $92 \cdot 3$ \\
\hline S. subterranea & SMCC B0478 & U20773 & $92 \cdot 3$ \\
\hline S. subarctica & HAMBI $2110^{\mathrm{T}}$ & X94102 & $91 \cdot 8$ \\
\hline S. herbicidovorans & DSM $11019^{T}$ & AB022428 & $91 \cdot 5$ \\
\hline S. capsulata & ATCC $14666^{\mathrm{T}}$ & D16147 & $91 \cdot 1$ \\
\hline Erythrobacter longus & JCM $6170^{\mathrm{T}}$ & D12699 & $91 \cdot 1$ \\
\hline S. macrogoltabidus & IFO $15033^{T}$ & D13723 & $91 \cdot 0$ \\
\hline S. terrae & IFO $15098^{\mathrm{T}}$ & D13727 & $90 \cdot 8$ \\
\hline Agrobacterium tumefaciens & DSM 30150 & M11223 & $86 \cdot 1$ \\
\hline
\end{tabular}

representatives of the other branches are characterized by spermidine as the major compound. Despite this phylogenetic and chemotaxonomic heterogeneity, three species (Blastomonas natatoria, Rhizomonas suberifaciens and Erythromonas ursincola) have been reclassified recently in the genus Sphingomonas (Yabuuchi et al., 1999), expanding the heterogeneity of the genus still further, because, as shown by Takeuchi et al. (1999), these three genera can be distinguished clearly from the four major branches of Sphingomonas by means of signature nucleotides in the 16S rRNA gene. As a consequence, the genus Sphingomonas, as it is now recognized, will ultimately be reclassified into at least three new genera, with only those species in the $S$. paucimobilis branch being maintained within the genus Sphingomonas. Very recently, it has been confirmed that B. natatoria and Erythromonas ursincola are distinct from the genus Sphingomonas (Hiraishi et al., 2000). In conclusion, in view of the phylogenetic distance from members of the $S$. paucimobilis branch, we have used the basonyms $B$. natatoria and $R$. suberifaciens in this study.

16S rRNA gene sequence analysis placed the novel exopolysaccharide-producing bacterial isolate $\mathrm{EDIV}^{\mathrm{T}}$ within the cluster considered as the genus Sphingomonas sensu stricto. The $\mathrm{G}+\mathrm{C}$ content of the DNA, the presence of ubiquinone Q-10, the presence of 14:0 $2-\mathrm{OH}$ as the major hydroxylated fatty acid, the absence of 3-hydroxylated fatty acids, the presence of sphingoglycolipid and the absorbance spectrum of the yellow pigment all supported this allocation, confirmed by the detection of sym-homospermidine as the major compound in the polyamine pattern.

Comparative analysis of the 16S rRNA gene sequence and estimation of the phylogenetic relationships indicated that EDIV $^{\mathrm{T}}$ is closely related ( $99.4 \%$ similarity) to $S$. trueperi LMG $2142^{\mathrm{T}}$. On the other hand, the 
DNA-DNA relatedness $(45 \cdot 5 \%)$ between strain EDIV $^{\mathrm{T}}$ and $S$. trueperi ATCC $12417^{\mathrm{T}}\left(=\mathrm{LMG} 2142^{\mathrm{T}}\right)$ was below the threshold value (approx. $70 \%$ ) that has been suggested as delineating a bacterial species (Wayne et al., 1987), indicating clearly that strain EDIV $^{\mathrm{T}}$ represents a distinct species. Comparison of the FT-IR spectra showed numerous differences in the polysaccharide regions of strains EDIV ${ }^{\mathrm{T}}$ and ATCC $12417^{\mathrm{T}}$ that would be consistent with differences observed in the whole-cell protein patterns of the two strains (data not shown). These results reflect differences in the genomic content of the organism, again suggesting that strain EDIV $^{\mathrm{T}}$ constitutes a separate species.

Results obtained from cellular fatty acid and polar lipid analyses were also unique and distinguished strain EDIV $^{\mathrm{T}}$ from its phylogenetic neighbour, S. trueperi, as well as differentiating it from other sym-homospermidine-containing Sphingomonas species. Quantitative differences in the fatty acid composition distinguished EDIV ${ }^{\mathrm{T}}$ from $S$. trueperi as well as from other species of the S. paucimobilis branch (Table 2). Remarkably, strain EDIV ${ }^{\mathrm{T}}$ possessed 2-hydroxypentadecanoic acid (15:0 2-OH), a feature unique for a member of this branch. Until now, 15:0 2-OH has been detected only in the distantly related species S. terrae, Sphingomonas stygia, Sphingomonas subterranea and Sphingomonas aromaticivorans (Kämpfer et al., 1997; Stolz et al., 2000), which are located on other branches of the genus Sphingomonas (Fig. 3), and has not been detected so far in representatives of the $S$. paucimobilis branch. The overall polar lipid pattern of EDIV ${ }^{\mathrm{T}}$ was similar to those found in other Sphingomonas species (Kämpfer et al., 1997; Denner et al., 1999). As shown previously in our laboratory, the polar lipid composition differs qualitatively and quantitatively between Sphingomonas species, and identical polar lipid patterns are observed only in close relatives such as $S$. asaccharolytica and S. mali (Kämpfer et al., 1997). Strain EDIV ${ }^{\mathrm{T}}$ was distinguishable from its closest phylogenetic neighbour, S. trueperi, because of the absence of an unknown polar lipid (PL1) described for $S$. trueperi and the presence of an unknown aminolipid (APL1) not detected in $S$. trueperi (Kämpfer et al., 1997). EDIV ${ }^{\mathrm{T}}$ was also different from $S$. trueperi in a significant number of biochemical traits; for example, strain EDIV $^{\mathrm{T}}$ lacked oxidase activity, hydrolysed aesculin, assimilated L-proline and was unable to assimilate D-fructose, maltitol, propionate, glutarate, DL-lactate, L-aspartate, L-leucine, L-serine and 4-hydroxybenzoate. The absence of oxidase activity in strain EDIV $^{\mathrm{T}}$ is an almost unique biochemical trait that has been reported for only a few strains of Sphingomonas (Yabuuchi et al., 1990). This is particularly interesting since all of the known sphingan-producing Sphingomonas strains are also oxidase-negative (Pollock, 1993); perhaps some of these strains are related to strain EDIV ${ }^{\mathrm{T}}$.

Furthermore, our first investigations of the extracellular material secreted by the bacterium revealed that it is a heteropolysaccharide (hereafter named PSEDIV) with a mean molecular mass of approx. $3 \times 10^{6}$ $\mathrm{Da}$, composed of glucose and rhamnose, as well as an unidentified sugar; no uronic acids or sulfates were found in PS-EDIV. The fact that glucuronic acid (which is usually found in sphingans; Pollock, 1993) was not detected in PS-EDIV is an unusual result. To our knowledge, glucuronic acid is absent only in the sphingan PS-P4. This exopolysaccharide has been known to be produced by $S$. paucimobilis strain $\mathrm{P} 4$ (DSM 6418) (Lobas et al., 1994), a strain that was isolated by a selective culturing method (Lobas et al., 1992) from a culture of $[P$.] paucimobilis NCIB 11942 (Anson et al., 1987). Also of particular interest is the fact that PS-EDIV does not contain L-mannose, which has been found as a constituent of sphingans S-130, S88, S-198 and NW-11 (Jansson et al., 1985, 1986; Chowdhury et al., 1987a; Robison \& Stipanovic, 1989). In addition, there is some similarity between exopolysaccharides produced by $[P$.] paucimobilis RMPD strains 17a and 17b (Hebbar et al., 1992). The carbohydrate-backbone structures of these exopolysaccharides are also composed of glucose and rhamnose and also lack L-mannose and uronic acids. However, the reported chemical analyses of all of these exopolysaccharides indicated that they are quite different from PS-EDIV. There is strong evidence from our chemical analyses that the extracellular material secreted by strain EDIV $^{\mathrm{T}}$ is a novel type of exopolysaccharide within the sphingan family. Further studies on the chemical and physical properties of PS-EDIV are in progress.

In summary, this polyphasic investigation clearly demonstrates that strain EDIV $^{\mathrm{T}}$ represents a new species within the genus Sphingomonas sensu stricto, for which we propose the name Sphingomonas pituitosa sp. nov.

\section{Description of Sphingomonas pituitosa sp. nov.}

Sphingomonas pituitosa (pi.tu.i.to'sa. L. fem. adj. pituitosa slimy).

Cells are Gram-negative, rod-shaped, non-sporeforming and motile (each cell has a polar monotrichous flagellum). Cells are 0.4-0.75 $\mu \mathrm{m}$ wide and $1.0-3.0 \mu \mathrm{m}$ long. Strictly aerobic. Yellow intracellular pigments (carotenoids) are produced; the visible absorption spectrum of the yellow pigment (acetone extract) has two peaks at $\lambda_{\max } 452$ and $478 \mathrm{~nm}$ and a slight inflexion at $425 \mathrm{~nm}$. Poly- $\beta$-hydroxybutyrate is accumulated. Colonies on complex, peptone-containing standard media are deep yellow, circular, entire, convex and smooth. Capable of growth at room temperature and at $30^{\circ} \mathrm{C}$ but not at 4,37 or $45^{\circ} \mathrm{C}$. Capable of growth on nutrient-reduced media such as Czapek-Dox and R2A. No growth on Simmons citrate agar. Positive reactions are obtained for catalase and $\beta$-galactosidase. No reactions are obtained for oxidase, arginine dihydrolase, urease, nitrate reduction, production of 
indole, gelatin liquefaction or $\mathrm{H}_{2} \mathrm{~S}$ production. Tween 80 is hydrolysed but starch, casein and DNA are not. Susceptible to ampicillin, chloramphenicol, gentamicin, kanamycin and tetracycline; resistant to penicillin $\mathrm{G}$, polymyxin $\mathrm{B}$ and streptomycin. The following compounds are assimilated: $N$-acetyl Dglucosamine, L-arabinose, $p$-arbutin, D-cellobiose, D-galactose, D-glucose, D-mannose, D-maltose, $\alpha$-Dmelibiose, sucrose, salicin, D-trehalose, D-xylose, acetate, fumarate, DL-3-hydroxybutyrate, L-malate, pyruvate, L-alanine and L-proline. The following compounds are not assimilated: D-fructose, gluconate, Lrhamnose, D-ribose, adonitol, $i$-inositol, maltitol, D-sorbitol, D-mannitol, putrescine, propionate, cisaconitate, trans-aconitate, adipate, 4-aminobutyrate, azelate, citrate, glutarate, itaconate, DL-lactate, mesaconate, oxoglutarate, suberate, $\beta$-alanine, L-aspartate, L-histidine, L-leucine, L-ornithine, L-phenylalanine, Lserine, L-tryptophan, 3-hydroxybenzoate, 4-hydroxybenzoate and phenylacetate. The following compounds are hydrolysed: aesculin, para-nitrophenyl (pNP) $\beta$-D-galactopyranoside, $\mathrm{pNP} \beta$-D-glucuronide, pNP $\alpha$-D-glucopyranoside, pNP $\beta$-D-glucopyranoside, $\mathrm{pNP} \beta$-xylopyranoside, bis-pNP phosphate, $\mathrm{pNP}$ phenylphosphate, pNP phosphoryl-choline, 2-deoxythymidine-5'-pNP phosphate, L-alanine-para-nitroanilide (pNA) and L-glutamate- $\gamma-3$-carboxy-pNA. LProline-pNA is not hydrolysed. Weak production of acid can be observed, after prolonged incubation, from D-glucose, lactose, sucrose, L-arabinose, L-rhamnose, maltose, D-xylose and cellobiose. No acids are produced from D-mannitol, dulcitol, salicin, adonitol, inositol, sorbitol, raffinose, trehalose, methyl $\alpha$-Dglucoside, erythritol, melibiose, D-arabitol or D-mannose. Phylogenetically, S. pituitosa clusters with the validly published species of the genus Sphingomonas within the $\alpha$-subclass of the Proteobacteria (Woese, 1987; Stackebrandt et al., 1988). The $\mathrm{G}+\mathrm{C}$ content of the DNA is $64.5 \mathrm{~mol} \%$. Ubiquinone Q- 10 is the major respiratory lipoquinone. sym-Homospermidine is the major component in the polyamine pattern. The major polar lipids are phosphatidylethanolamine, phosphatidyldimethylethanolamine, phosphatidylglycerol and an unknown lipid (L1). Diphosphatidylglycerol, phosphatidylmonomethanolamine and phosphatidylcholine, as well as several unknown lipids, are present in minor concentrations. Sphingoglycolipid is present. The predominant non-polar fatty acids are 18:1 and 16:0; the major 2-hydroxy fatty acid is 14:0 2-OH, but minor amounts of 15:0 $2-\mathrm{OH}$ are also present. Isolated from the water of a eutrophic fountain in Vienna, Austria, in which an algal bloom was observed. The type strain is EDIV ${ }^{\mathrm{T}}$ $\left(=\right.$ CIP $106154^{\mathrm{T}}=$ DSM $\left.13101^{\mathrm{T}}\right)$.

\section{ACKNOWLEDGEMENTS}

We gratefully acknowledge Professor H. G. Trüper, University of Bonn, Germany, for the etymological evaluation. E. B. M. D. acknowledges Dr F. Mertens (Bruker, Karlsruhe, Germany) for supplying the IFS28/B instrument and for excellent technical support and G. Schroll for the evaluation of PHB accumulation by GC analysis. E. R.B.M. acknowledges A. Krüger for technical support during nucleic acid sequence determination. P.K. is indebted to the German Ministry of Education and Research (BMBF) for a grant (BEO 0311768).

\section{REFERENCES}

Anderson, G. R. (1955). Nitrogen fixation by Pseudomonas-like soil bacteria. J Bacteriol 70, 129-133.

Anson, A., Fisher, P. J., Kennedy, A. F. D. \& Sutherland, I. W. (1987). A bacterium yielding a polysaccharide with unusual properties. J Appl Microbiol 62, 147-150.

Ashtaputre, A. A. \& Shah, A. K. (1995). Studies on a viscous, gelforming exopolysaccharide from Sphingomonas paucimobilis GS1. Appl Environ Microbiol 61, 1159-1162.

Atlas, R. M. (1995). Handbook of Microbiological Media. Boca Raton, FL: CRC Press.

Azeredo, J. \& Olivera, R. (1996). A new method for precipitating bacterial exopolysaccharides. Biotechnol Tech 10, 341-344.

Balkwill, D. L., Drake, G. R., Reeves, R. H. \& 7 other authors (1997). Taxonomic study of aromatic-degrading bacteria from deep-terrestrial-subsurface sediments and description of Sphingomonas aromaticivorans sp. nov., Sphingomonas subterranea sp. nov., and Sphingomonas stygia sp. nov. Int J Syst Bacteriol 47, 191-201.

Beiss, U. (1964). Zur papierchromatographischen Auftrennung von Pflanzenlipiden. J Chromatogr 13, 104.

Berg, G. \& Balin, G. (1994). Bacterial antagonists to Verticillium dahliae Kleb. J Phytopathol 141, 99-110.

Bligh, E. G. \& Dyer, W. J. (1959). A rapid method of total lipid extraction and purification. Can J Biochem Physiol 37, 911-917.

van Bruggen, A. H. C., Jochimsen, K. N., Steinberger, E. M., Segers, P. \& Gillis, M. (1993). Classification of Rhizomonas suberifaciens, an unnamed Rhizomonas species, and Sphingomonas spp. in rRNA superfamily IV. Int $J$ Syst Bacteriol 43, $1-7$.

Busse, J. \& Auling, G. (1988). Polyamine pattern as a chemotaxonomic marker within the Proteobacteria. Syst Appl Microbiol 11, 1-8.

Busse, H.-J., Bunka, S., Hensel, A. \& Lubitz, W. (1997). Discrimination of members of the family Pasteurellaceae based on polyamine patterns. Int J Syst Bacteriol 47, 698-708.

Busse, H.-J., Kämpfer, P. \& Denner, E. B. M. (1999). Chemotaxonomic characterisation of Sphingomonas. J Ind Microbiol Biotechnol 23, 242-251.

Cashion, P., Holder-Franklin, M. A., McCully, J. \& Franklin, M. (1977). A rapid method for the base ratio determination of bacterial DNA. Anal Biochem 81, 461-466.

Chandrasekaran, R. \& Radha, A. (1995). Molecular architectures and functional properties of gellan gum and related polysaccharides. Trends Food Sci Technol 6, 143-148.

Chowdhury, T. A., Lindberg, B., Lindquist, U. \& Baird, J. (1987a). Structural studies of an extracellular polysaccharide (S-198) elaborated by Alcaligenes ATCC 31853. Carbohydr Res 161, 127-132.

Chowdhury, T. A., Lindberg, B., Lindquist, U. \& Baird, J. (1987b). Structural studies of an extracellular polysaccharide, S-657, elaborated by Xanthomonas ATCC 53159. Carbohydr Res 164, 117-122.

Collins, M. D. (1994). Isoprenoid quinones. In Chemical Methods 
in Prokaryotic Systematics, pp. 265-309. Edited by $\mathrm{M}$. Goodfellow \& A. G. O'Donnell. Chichester: Wiley.

Consden, R. \& Gordon, A. H. (1948). The effect of salt on partition chromatograms. Nature 162, 180-181.

De Ley, J., Cattoir, H. \& Reynaerts, A. (1970). The quantitative measurement of DNA hybridization from renaturation rates. Eur J Biochem 12, 133-142.

Denner, E. B. M., Kämpfer, P., Busse, H.-J. \& Moore, E. R. B. (1999). Reclassification of Pseudomonas echinoides Heumann 1962, 343 ${ }^{\mathrm{AL}}$, in the genus Sphingomonas as Sphingomonas echinoides comb. nov. Int J Syst Bacteriol 49, 1103-1109.

Dittmer, J. C. F. \& Lester, R. L. (1964). A simple specific spray for the detection of phospholipids in thin layer chromatograms. $J$ Lipid Res 5, 126-127.

Escara, J. F. \& Hutton, J. R. (1980). Thermal stability and renaturation of DNA in dimethyl sulfoxide solutions: acceleration of the renaturation rate. Biopolymers 19, 1315-1327.

Falk, C., Jansson, P.-E., Rinaudo, M., Heyraud, A., Widmalm, G. \& Hebbar, P. (1996). Structural studies of the exocellular polysaccharide from Sphingomonas paucimobilis strain I-886. Carbohydr Res 285, 69-79.

Felsenstein, J. (1985). Confidence limits on phylogenies: an approach using the bootstrap. Evolution 39, 783-791.

Felsenstein, J. (1993). PHYLIP (Phylogeny Inference Package) version 3.5c. University of Washington, Seattle, WA, USA.

Fox, G. E., Wisotzkey, J. D. \& Jurtshuk, P., Jr (1992). How close is close: $16 \mathrm{~S}$ rRNA sequence identity may not be sufficient to guarantee species identity. Int J Syst Bacteriol 42, 166-170.

Fredrickson, J. K., Brockman, F. J., Workman, D. J., Li, S. W. \& Stevenson, T. O. (1991). Isolation and characterization of a subsurface bacterium capable of growth on toluene, naphthalene, and other aromatic compounds. Appl Environ Microbiol 57, 796-803.

Fredrickson, J. K., Balkwill, D. L., Drake, G. R., Romine, M. F., Ringelberg, D. B. \& White, D. C. (1995). Aromatic-degrading Sphingomonas isolates from the deep subsurface. Appl Environ Microbiol 61, 1917-1922.

Gunstone, F. D. \& Jacobsberg, F. R. (1972). Fatty acids, part 35: the preparation and properties of a complete series of methyl epoxyoctadecanoates. Chem Phys Lipids 9, 26-64.

Gutell, R. R., Weiser, B., Woese, C. R. \& Noller, H. F. (1985). Comparative anatomy of $16 \mathrm{~S}$-like ribosomal RNA. Prog Nucleic Acid Res Mol Biol 32, 155-216.

Harms, H., Wilkes, H., Wittich, R. \& Fortnagel, P. (1995). Metabolism of hydroxydibenzofurans, methoxydibenzofurans, acetoxydibenzofurans, and nitrodibenzofurans by Sphingomonas sp. strain HH69. Appl Environ Microbiol 61, 2499-2505.

Hashimoto, W. \& Murato, K. (1998). $\alpha$-Rhamnosidase of Sphingomonas sp. R1 producing an unusual exopolysaccharide of sphingan. Biosci Biotechnol Biochem 62, 1068-1074.

Hebbar, K. P., Gueniot, B., Heyraud, A., Colin-Morel, P., Heulin, T. \& Rinaudo, M. (1992). Characterization of exopolysaccharides produced by rhizobacteria. Appl Microbiol Biotechnol 38, 248-253.

Helm, D., Labischinski, H. \& Naumann, D. (1991a). Elaboration of a procedure for identification of bacteria using Fouriertransform IR spectral libraries: a stepwise correlation approach. J Microbiol Methods 14, 127-142.

Helm, D., Labischinski, H., Schallehn, G. \& Naumann, D. (1991b). Classification and identification of bacteria by Fourier-transform infrared spectroscopy. J Gen Microbiol 137, 69-79.
Heumann, W. (1962). Die Methodik der Kreuzung sternbildender Bakterien. Biol Zentbl 81, 341-354.

Hiraishi, A., Kuraishi, H. \& Kawahara, K. (2000). Emendation of the description of Blastomonas natatoria (Sly 1985) Sly and Cahill 1997 as an aerobic photosynthetic bacterium and reclassification of Erythromonas ursincola Yurkov et al. 1997 as Blastomonas ursincola comb. nov. Int J Syst Evol Microbiol 50, 1113-1118.

Huss, V. A. R., Festl, H. \& Schleifer, K. H. (1983). Studies on the spectrometric determination of DNA hybridization from renaturation rates. Syst Appl Microbiol 4, 184-192.

Huu, N. B., Denner, E. B. M., Ha, D. T. C., Wanner, G. \& StanLotter, H. (1999). Marinobacter aquaeolei sp. nov., a halophilic bacterium isolated from a Vietnamese oil-producing well. Int $J$ Syst Bacteriol 49, 367-375.

Ishizuka, I., Suzuki, M. \& Yamakawa, T. (1973). Isolation and characterization of a novel sulfoglycolipid, 'seminolipid,' from boar testis and spermatozoa. $J$ Biochem 73, 77-87.

Jacin, H. \& Mishkin, A. R. (1965). Separation of carbohydrates on borate impregnated silica gel $\mathrm{G}$ plates. J Chromatogr 18, 170-173.

Jackman, P. J. H. (1987). Microbial systematics based on electrophoresis whole-cell protein patterns. Methods Microbiol 1, 209-225.

Jahnke, K.-D. (1992). Basic computer program for evaluation of spectroscopic DNA renaturation data from Gilford System 2600 spectrometer on a PC/XT/AT type personal computer. $J$ Microbiol Methods 15, 61-73.

Jansson, P. E., Lindberg, B., Widmalm, G. \& Sandford, P. A. (1985). Structural studies of an extracellular polysaccharide (PS-130) elaborated by Alcaligenes ATCC 31555. Carbohydr Res 139, 217-223.

Jansson, P. E., Kumar, N. S. \& Lindberg, B. (1986). Structural studies of a polysaccharide (S-88) elaborated by Pseudomonas ATCC 31554. Carbohydr Res 156, 165-172.

Jenkins, C. L., Andrews, A. G., McQuade, T. J. \& Starr, M. P. (1979). The pigment of Pseudomonas paucimobilis is carotenoid (nostoxanthin), rather than a brominated aryl-polyene (xanthomonadin). Curr Microbiol 3, 1-4.

Jorgensen, J. H., Turnidge, J. D. \& Washington, J. A. (1999). Antibacterial susceptibility tests: dilution and disk diffusion methods. In Manual of Clinical Microbiology, pp. 1526-1543. Edited by P. R. Murray, E. J. Baron, M. A. Pfaller, F. C. Tenover \& R. H. Yolken. Washington, DC: American Society for Microbiology.

Jukes, T. H. \& Cantor, C. R. (1969). Evolution of protein molecules. In Mammalian Protein Metabolism, pp. 21-132. Edited by H. N. Munro. New York: Academic Press.

Kämpfer, P. \& Altwegg, M. (1992). Numerical classification and identification of Aeromonas genospecies. J Appl Bacteriol 72, 341-351.

Kämpfer, P. \& Kroppenstedt, R. M. (1996). Numerical analysis of fatty acid patterns of coryneform bacteria and related taxa. Can J Microbiol 42, 989-1005.

Kämpfer, P., Steiof, M. \& Dott, W. (1991). Microbiological characterization of a fuel oil contaminated site including numerical identification of heterotrophic water and soil bacteria. Microb Ecol 21, 227-251.

Kämpfer, P., Denner, E. B. M., Meyer, S., Moore, E. R. B. \& Busse, H.-J. (1997). Classification of 'Pseudomonas azotocolligans' Anderson 1955, 132, in the genus Sphingomonas as Sphingomonas trueperi sp. nov. Int J Syst Bacteriol 47, 577-583. 
Kaneko, T., Katoh, K., Fujimoto, M., Kumagi, M., Tamaoka, J. \& Katayama-Fujimura, Y. (1986). Determination of the nucleotide composition of a deoxyribonucleic acid by high-performance liquid chromatography of its enzymatic hydrolysates. $J$ Microbiol Methods 4, 229-240.

Kang, K. S. \& McNeely, W. H. (1976). Polysaccharide and bacterial fermentation process for its preparation. United States Patent 3960832.

Kang, K. S. \& Veeder, G. T. (1982a). Polysaccharide S-60 and bacterial fermentation process for its preparation. United States Patent 4326053.

Kang, K. S. \& Veeder, G. T. (1982b). Heteropolysaccharide S-130. United States Patent 4342866.

Kang, K. S. \& Veeder, G. T. (1985). Heteropolysaccharide $S-88$. United States Patent 4535153.

Kang, K. S., Veeder, G. T., Mirrasoul, P. J., Kaneto, T. \& Cottrell, I. W. (1982). Agar-like polysaccharide produced by a Pseudomonas species: production and basic properties. Appl Environ Microbiol 43, 1086-1091.

Karlson, U., Rojo, F., van Elsas, J. D. \& Moore, E. R. B. (1995). Genetic and serological evidence for the recognition of four pentachlorophenol-degrading bacterial strains as a species of the genus Sphingomonas. Syst Appl Microbiol 18, 539-548.

Kodaka, H., Armfield, A. Y., Lombard, G. L. \& Dowell, V. R. (1982). Practical procedure for demonstrating bacterial flagella. J Clin Microbiol 16, 948-952.

Laemmli, U. K. (1970). Cleavage of structural proteins during the assembly of the head of bacteriophage T4. Nature 227, 680-685.

Lobas, D., Schumpe, A. \& Deckwer, W.-D. (1992). The production of gellan exopolysaccharide with Sphingomonas paucimobilis E2 (DSM 6314). Appl Microbiol Biotechnol 37, 411-415.

Lobas, D., Nimtz, M., Wray, V., Schumpe, A., Proppe, C. \& Deckwer, W.-D. (1994). Structure and physical properties of the extracellular polysaccharide PS-P4 produced by Sphingomonas paucimobilis P4 (DSM 6418). Carbohydr Res 251, 303-313.

Maidak, B. L., Olsen, G. J., Larsen, N., Overbeek, R., McCaughey, M. J. \& Woese, C. R. (1996). The Ribosomal Database Project (RDP). Nucleic Acids Res 24, 82-85.

Maidak, B. L., Cole, J. R., Parker, C. T. \& 11 other authors (1999). A new version of the RDP (Ribosomal Database Project). Nucleic Acids Res 27, 171-173.

Marmur, J. (1961). A procedure for the isolation of desoxyribonucleic acid from microorganisms. J Mol Biol 3, 208-218.

Moorehouse, R. (1987). Structure/property relationships of a family of microbial polysaccharides. In Industrial Polysaccharides: Genetic Engineering, Structure, Structure/Property Relations and Applications, pp. 187-206. Edited by M. Yalpani. Amsterdam: Elsevier.

Mueller, J. G., Chapman, P. J., Blattmann, B. O. \& Pritchard, P. H. (1990). Isolation and characterization of a fluoranthene-utilizing strain of Pseudomonas paucimobilis. Appl Environ Microbiol 56, 1079-1086.

Naumann, D., Helm, D. \& Labischinski, H. (1991). Microbiological characterizations by FT-IR spectroscopy. Nature 351, 81-82.

Nohynek, L. J., Suhonen, E. L., Nurmiaho-Lassila, E.-L., Hantula, J. \& Salkinoja-Salonen, M. (1996a). Description of four pentachlorophenol-degrading bacterial strains as Sphingomonas chlorophenolica sp. nov. Syst Appl Microbiol 18, 527-538.

Nohynek, L. J., Nurmiaho-Lassila, E.-L., Suhonen, E. L., Busse, H.-J., Mohammadi, M., Hantula, J., Rainey, F. \& Salkinoja-Salonen, M. S. (1996b). Description of chlorophenol-degrading Pseudo- monas sp. strains $\mathrm{KF} 1^{\mathrm{T}}$, $\mathrm{KF} 3$, and $\mathrm{NKF} 1$ as a new species of the genus Sphingomonas, Sphingomonas subarctica sp. nov. Int $J$ Syst Bacteriol 46, 1042-1055.

O'Neill, M. A., Selvendran, R. R. \& Morris, J. V. (1983). Structure of the acidic extracellular gelling polysaccharide produced by Pseudomonas elodea. Carbohydr Res 124, 123-133.

Owen, R. J. \& Jackman, P. J. H. (1982). The similarities between Pseudomonas paucimobilis and allied bacteria derived from analysis of deoxyribonucleic acids and electrophoretic protein patterns. J Gen Microbiol 128, 2945-2954.

Peik, J. A., Steenbergen, S. M. \& Hayden, H. R. (1983). Heteropolysaccharide $S$-194. United States Patent 4401760.

Peik, J. A., Steenbergen, S. M. \& Hayden, H. R. (1985). Heteropolysaccharide $S$-198. United States Patent 4529797.

Pollock, T. J. (1993). Gellan-related polysaccharides and the genus Sphingomonas. J Gen Microbiol 139, 1939-1945.

Porter, K. \& Feig, Y. S. (1990). The use of DAPI for identifying and counting aquatic microflora. Limnol Oceanogr 25, 943-948.

Raguenes, G., Pignet, P., Gauthier, G., Peres, A., Christen, R., Rougeaux, H., Barbier, G. \& Guezennec, J. (1996). Description of a new polymer-secreting bacterium from a deep-sea hydrothermal vent, Alteromonas macleodii subsp. fijiensis, and preliminary characterization of the polymer. Appl Environ Microbiol 62, 67-73.

Reasoner, D. J. \& Geldreich, E. E. (1985). A new medium for the enumeration and subculture of bacteria from potable water. Appl Environ Microbiol 49, 1-7.

Robison, P. D. \& Stipanovic, A. J. (1989). Method for oil recovery using a modified heteropolysaccharide. United States Patent 4874044.

Schroll, G., Denner, E. B. M., Rölleke, S., Lubitz, W. \& Busse, H.-J. (1996). Characterization of a new Pseudomonas isolate, capable of accumulating polyesters of medium chain length 3hydroxyalkanoic acids. J Biotechnol 47, 53-63.

Segers, P., Vancanneyt, M., Pot, B., Torck, U., Hoste, B., Dewettinck, D., Falsen, E., Kersters, K. \& De Vos, P. (1994). Classification of Pseudomonas diminuta Leifson and Hugh 1954 and Pseudomonas vesicularis Büsing, Döll, and Freytag 1953 in Brevundimonas gen. nov. as Brevundimonas diminuta comb. nov. and Brevundimonas vesicularis comb. nov., respectively. Int $J$ Syst Bacteriol 44, 499-510.

Sherr, B. F., Sherr, E. B. \& McDaniel, J. (1992). Effect of protistan grazing on the frequency of dividing cells in bacterioplankton assemblages. Appl Environ Microbiol 58, 2381-2385.

Smibert, R. M. \& Krieg, N. R. (1994). Phenotypic characterization. In Methods for General and Molecular Bacteriology, pp. 607-654. Edited by P. Gerhardt, R. G. E. Murray, W. A. Woods \& N. R. Krieg. Washington, DC: American Society for Microbiology.

Stackebrandt, E., Murray, R. G. E. \& Trüper, H. G. (1988). Proteobacteria classis nov., a name for the phylogenetic taxon that includes the 'purple bacteria and their relatives'. Int J Syst Bacteriol 38, 321-325.

Stoesser, G., Tuli, M. A., Lopez, R. \& Sterk, P. (1999). The EMBL nucleotide sequence database. Nucleic Acids Res 27, 18-24.

Stolz, A., Schmidt-Maag, C., Denner, E. B. M., Busse, H.-J., Egli, T. \& Kämpfer, P. (2000). Description of Sphingomonas xenophaga sp. nov. for strains $\mathrm{BN}^{\mathrm{T}}$ and $\mathrm{N}, \mathrm{N}$ which degrade xenobiotic aromatic compounds. Int J Syst Evol Microbiol 50, 35-41.

Takeuchi, M., Kawai, F., Shimada, Y. \& Yokota, A. (1993). Taxonomic study of polyethylene glycol-utilizing bacteria: emended description of the genus Sphingomonas and new 
descriptions of Sphingomonas macrogoltabidus sp. nov., Sphingomonas sanguis sp. nov., and Sphingomonas terrae sp. nov. Syst Appl Microbiol 16, 227-238.

Takeuchi, M., Sawada, H., Oyaizu, H. \& Yokota, A. (1994). Phylogenetic evidence for Sphingomonas and Rhizomonas as nonphotosynthetic members of the alpha-4 subclass of the Proteobacteria. Int J Syst Bacteriol 44, 308-314.

Takeuchi, M., Sakane, T., Yanagi, M., Yamasato, K., Hamana, K. \& Yokota, A. (1995). Taxonomic study of bacteria isolated from plants: proposal of Sphingomonas rosa sp. nov., Sphingomonas pruni sp. nov., Sphingomonas asaccharolytica sp. nov., and Sphingomonas mali sp. nov. Int J Syst Bacteriol 45, 334-341.

Takeuchi, M., Hiraishi, A., Hamana, K. \& Hatano, K. (1999). Proposal of the genus Sphingomonas sensu stricto and three new genera based on the analysis of $16 \mathrm{~S}$ ribosomal RNA sequence and polyamine profile. In Proceedings of the 9th Annual Meeting of ICBAM, 1999, p. 86, BPO 11.5.

Tamaoka, J. \& Komagata, K. (1984). Determination of DNA base composition by reverse-phase high performance liquid chromatography. FEMS Microbiol Lett 25, 125-128.

Tindall, B. J. (1990). Lipid composition of Halobacterium lacusprofundi. FEMS Microbiol Lett 66, 199-202.

Vauterin, L., Swings, J. \& Kersters, K. (1993). Protein electrophoresis and classification. In Handbook of New Bacterial Systematics, pp. 251-280. Edited by M. Goodfellow \& A. G. O'Donnell. London: Academic Press.

Wagner, H., Hörhammer, L. \& Wolff, P. (1961). Dünnschichtchromatographie von Phosphatiden und Glykolipiden. Biochem Z 234, 12-21.

Wayne, L. G., Brenner, D. J., Colwell, R. R. \& 9 other authors (1987). Report of the ad hoc committee on reconciliation of approaches to bacterial systematics. Int J Syst Bacteriol 37, 463-464
Witte, A., Wanner, G., Bläsi, U., Halfmann, G., Szostak, M. \& Lubitz, W. (1990). Endogenous transmembrane tunnel formation mediated by $\phi \mathrm{X} 174$ lysis protein E. J Bacteriol 172, 4109-4114.

Wittich, R.-M., Wilkes, H., Sinnwell, V., Francke, W. \& Fortnagel, P. (1992). Metabolism of dibenzo-p-dioxin by Sphingomonas sp. strain RW1. Appl Environ Microbiol 58, 1005-1010.

Woese, C. R. (1987). Bacterial evolution. Microbiol Rev 51, 221-271.

Yabuuchi, E., Yano, I., Oyaizu, H., Hashimoto, Y., Ezaki, T. \& Yamamoto, H. (1990). Proposals of Sphingomonas paucimobilis gen. nov. and comb. nov., Sphingomonas parapaucimobilis sp. nov., Sphingomonas yanoikuyae sp. nov., Sphingomonas adhaesiva sp. nov., Sphingomonas capsulata comb. nov., and two genospecies of the genus Sphingomonas. Microbiol Immunol 34, 99-119.

Yabuuchi, E., Kosako, Y., Naka, T., Suzuki, S. \& Yano, I. (1999). Proposal of Sphingomonas suberifaciens (van Bruggen, Jochimsen and Brown 1990) comb. nov., Sphingomonas natatoria (Sly 1985) comb nov., Sphingomonas ursincola (Yurkov et al. 1997) comb. nov., and emendation of the genus Sphingomonas. Microbiol Immunol 43, 339-349.

Yun, N. R., Shin, Y. K., Hwang, S. Y., Kuraishi, H., Sugiyama, J. \& Kawahara, K. (2000). Chemotaxonomic and phylogenetic analyses of Sphingomonas strains isolated from ears of plants in the family Gramineae and a proposal of Sphingomonas roseoflava sp. nov. J Gen Appl Microbiol 46, 9-18.

Zipper, C., Nickel, K., Angst, W. \& Kohler, H.-P. E. (1996). Complete microbial degradation of both enantiomers of the chiral herbicide Mecoprop [(RS)-2-(4-chloro-2-methylphenoxy)propionic acid] in an enantioselective manner by Sphingomonas herbicidovorans sp. nov. Appl Environ Microbiol 62, 4318-4322. 